\title{
Molecular Characterization of Membrane Steroid Receptors in Hormone-Sensitive Cancers
}

\author{
Mirco Masi ${ }^{1,2}$, Marco Racchi $^{1}{ }^{(\mathbb{D})}$, Cristina Travelli ${ }^{1}$ (D), Emanuela Corsini ${ }^{3, *(D)}$ and Erica Buoso ${ }^{1, *(D)}$ \\ 1 Dipartimento di Scienze del Farmaco, Università Degli Studi di Pavia, Viale Taramelli 12/14, \\ 27100 Pavia, Italy; mirco.masi@iusspavia.it (M.M.); racchi@unipv.it (M.R.); cristina.travelli@unipv.it (C.T.) \\ 2 Scuola Universitaria Superiore IUSS, Piazza della Vittoria 15, 27100 Pavia, Italy \\ 3 Laboratory of Toxicology, Dipartimento di Scienze Farmacologiche e Biomolecolari, Università Degli \\ Studi di Milano, Via Balzaretti 9, 20133 Milano, Italy \\ * Correspondence: emanuela.corsinini@unimi.it (E.C.); buoso.erica@gmail.com (E.B.)
}

Citation: Masi, M.; Racchi, M.; Travelli, C.; Corsini, E.; Buoso, E. Molecular Characterization of Membrane Steroid Receptors in Hormone-Sensitive Cancers. Cells 2021, 10, 2999. https://doi.org/ $10.3390 /$ cells10112999

Academic Editor: Satoshi Inoue

Received: 8 October 2021

Accepted: 2 November 2021

Published: 3 November 2021

Publisher's Note: MDPI stays neutral with regard to jurisdictional claims in published maps and institutional affiliations.

Copyright: (c) 2021 by the authors. Licensee MDPI, Basel, Switzerland. This article is an open access article distributed under the terms and conditions of the Creative Commons Attribution (CC BY) license (https:/ / creativecommons.org/licenses/by/ $4.0 /)$.
Abstract: Cancer is one of the most common causes of death worldwide, and its development is a result of the complex interaction of genetic factors, environmental cues, and aging. Hormone-sensitive cancers depend on the action of one or more hormones for their development and progression. Sex steroids and corticosteroids can regulate different physiological functions, including metabolism, growth, and proliferation, through their interaction with specific nuclear receptors, that can transcriptionally regulate target genes via their genomic actions. Therefore, interference with hormones' activities, e.g., deregulation of their production and downstream pathways or the exposition to exogenous hormone-active substances such as endocrine-disrupting chemicals (EDCs), can affect the regulation of their correlated pathways and trigger the neoplastic transformation. Although nuclear receptors account for most hormone-related biologic effects and their slow genomic responses are well-studied, less-known membrane receptors are emerging for their ability to mediate steroid hormones effects through the activation of rapid non-genomic responses also involved in the development of hormone-sensitive cancers. This review aims to collect pre-clinical and clinical data on these extranuclear receptors not only to draw attention to their emerging role in cancer development and progression but also to highlight their dual role as tumor microenvironment players and potential candidate drug targets.

Keywords: ZIP9; OXER1; GPRC6A; TRPM8; GPER; mPR; PGRMC; breast cancer; prostate cancer; ovarian cancer; endometrial cancer

\section{Introduction}

Cancer is one of the leading causes of death worldwide, with nearly 10 million deaths reported in 2020 [1]. The transformation of normal cells in tumor cells is a multistep process-from pre-cancerous lesions to the malignant tumor-that results from the interaction between genetic factors; environmental factors, such as chemical, physical, and biological carcinogens (as external agents); and aging. Among all types of tumors, those types that strictly depend on one or more hormones for growth, spread, and survival are defined hormone-sensitive cancers or hormone-dependent cancers. These include breast, ovarian, uterine (or endometrial), prostate, testis, and thyroid cancer [2].

Estrogen and progesterone appear to be the main sex hormones involved in growth of breast and uterine cancers, while ovarian and prostate cancers are mainly related to estrogens and androgens, respectively [2]. Breast and prostate cancers alone accounted for 2.26 and 1.41 million cases, respectively, in 2020. Although the type of tumor-initiating cues for hormone-sensitive cancers can be wide-ranging, the promotion event and subsequent growth and proliferation are driven by a hormone [2]. In addition to endogenous hormones, exogenous hormone-active substances, i.e., endocrine-active substances (EASs) and endocrine-disrupting chemicals (EDCs), can interact or interfere with the normal hormonal 
action and drive cell proliferation, thus increasing the cell division rate and, therefore, the consequent number of random genetic errors capable of triggering the cancerous transformation $[3,4]$.

Steroid hormones that are derived from cholesterol are divided into sex steroids (estrogens, androgens, and progestogens) and corticosteroids (glucocorticoids and mineralocorticoids). These hormones, by interacting with specific nuclear Steroid Receptors (nSRs), can regulate different physiological functions, including growth, development, metabolism, and reproduction [5]. Therefore, their abnormal production, deregulation of their signaling pathways, and interference with their action all play a role in supporting the growth, proliferation, and spread of hormone-sensitive cancers. Indeed, treatments for these cancer types are mostly based on the interruption of the hormonal stimuli, e.g., with inhibitors for key enzymes involved in hormone synthesis and with nSR antagonists. In addition to nSRs that produce slow genomic responses, other extranuclear steroid receptors have also been reported to mediate the biological effects of steroids. These membrane steroid receptors (mSRs) are cell surface receptors capable of mediating rapid and nongenomic signaling by modulating different intracellular molecular pathways that, through distinct signaling cascades, contribute to the regulation of steroid hormone-correlated functions $[6,7]$.

The aim of this review is to gather the existing scientific knowledge on mSRs to show their pivotal role in mediating the effects of steroid hormones and hormone-active substances in both physiologic and pathologic contexts; we also seek to elucidate their role as key players in shaping the cancer environment and, therefore, as potential drug targets.

\section{Membrane Steroid Receptors and Their Role in Hormone-Sensitive Cancers}

Steroid hormones can regulate gene expression in the nucleus but can also exert nongenomic functions by binding at or near the plasma membrane to induce rapid changes in cell physiology. Genetic and pharmacologic studies demonstrate mSRs function in different cell types and tissues where they respond to steroid ligands independently of the corresponding nSR. Some nSRs can exert their function at the plasma membrane, e.g., through post-translational modifications via palmitoylation or association with membrane scaffold proteins, to trigger cellular responses independently of their function as transcription factors [8]. In contrast, mSRs are integral membrane steroid receptors that feature transmembrane protein domains and, in response to steroid hormone binding, can activate or inactivate other proteins and second messenger cascades. Here, we focus on mSRs - which are lesser known and studied compared to their corresponding $\mathrm{nSR}$ - to dissect their molecular function and their pharmacology in hormone-sensitive cancers.

\subsection{Membrane Androgen Receptors}

In addition to the nSR known as Androgen Receptor (AR), other molecular mediators of the androgenic action include different plasma membrane receptors, namely, the Zinc Transporter Member 9 (ZIP9), the Oxoeicosanoid Receptor 1 (OXER1), the G proteincoupled receptor family $\mathrm{C}$ group 6 member A (GPRC6A), the $\mathrm{Ca}^{2+}$ channel Transient Receptor Potential Cation Channel Subfamily M (Melastatin) Member 8 (TRPM8) [9], and the L-type Voltage-dependent Calcium Channel (CaV1.2) [10].

\subsubsection{ZIP9}

ZIP9 (also known as Zrt- and Irt-like Protein 9 and Solute Carrier family 39 member 9, SLC39A9) is a $\mathrm{Zn}^{2+}$ transporter protein involved in the $\mathrm{Zn}^{2+}$ influx from the extracellular space to the cytoplasm [11] and a membrane Androgen Receptor (mAR) coupled to G proteins [12]. ZIP9, encoded by the SLC39A9 gene in human [12], is member 9 out of 14 ZIP family proteins and is present in three isoforms with different lengths and molecular weights. Unlike other ZIP proteins that feature 8 Trans-Membrane (TM) domains and an extracellular C-terminus, ZIP9 has a 7TM structure with an intracellular C-terminal domain and is the only member of the family to signal via $G$ protein [12]. In particu- 
lar, ZIP9 is coupled to a stimulatory $\mathrm{G} \alpha$ protein $(\mathrm{G} \alpha \mathrm{s})$, and, upon activation, it mediates Mitogen-Activated Protein kinase (MAPK) and $\mathrm{Zn}^{2+}$ signaling [13]. This dual role of $\mathrm{Zn}^{2+}$ transporter and $\mathrm{mAR}$ is exerted through $\mathrm{G}$ proteins involved in apoptotic pathways activated by androgens [12]. Indeed, testosterone exhibits high affinity for ZIP9 and has been demonstrated to act as an agonist for this receptor, while other endogenous androgens such as androstenedione and dihydrotestosterone (DHT) display low affinity [12]. Since $\mathrm{Zn}^{2+}$ is required for the structure of different proteins (e.g., zinc-finger-containing transcriptional factors and $\mathrm{Zn}^{2+}$-dependent metalloenzymes [14]) and for several signaling pathways involved in cell growth, proliferation, and apoptosis [14], $\mathrm{Zn}^{2+}$ homeostasis is pivotal for human health. Therefore, its dysregulation has been associated with different pathologies, including inflammation, diabetes, and cancer [14]. In this regard, ZIP9 has been found highly expressed and bound by androgen hormones in ovarian, breast and prostate cancer cells [15], and testosterone has been demonstrated to increase intracellular $\mathrm{Zn}^{2+}$ levels in the same hormone-sensitive tumors, where it led to high $\mathrm{Zn}^{2+}$ concentration-mediated apoptosis [12,16]. ZIP9 has been shown to mediate a testosterone-induced, AR-independent increase of cell migration in metastatic prostate cancer cells [17]. In contrast to previous literature data on ZIP9, testosterone treatment in human breast and prostate cancer cell lines results in the activation of an inhibitory $\mathrm{G} \alpha$ protein (G $\alpha \mathrm{i})$ [18]. Interestingly, ZIP9 was found significantly up-regulated in breast cancer tissues compared with normal breast tissues [19], the ZIP9-encoding SLC39A9 gene has been observed to form a fusion transcript with MAP3K9 gene (encoding for Mitogen-Activated Protein Kinase 9, MAP3K9), and the resulting fusion gene has been reported with repetitive incidence in different types of breast cancer [20] (Figure 1).

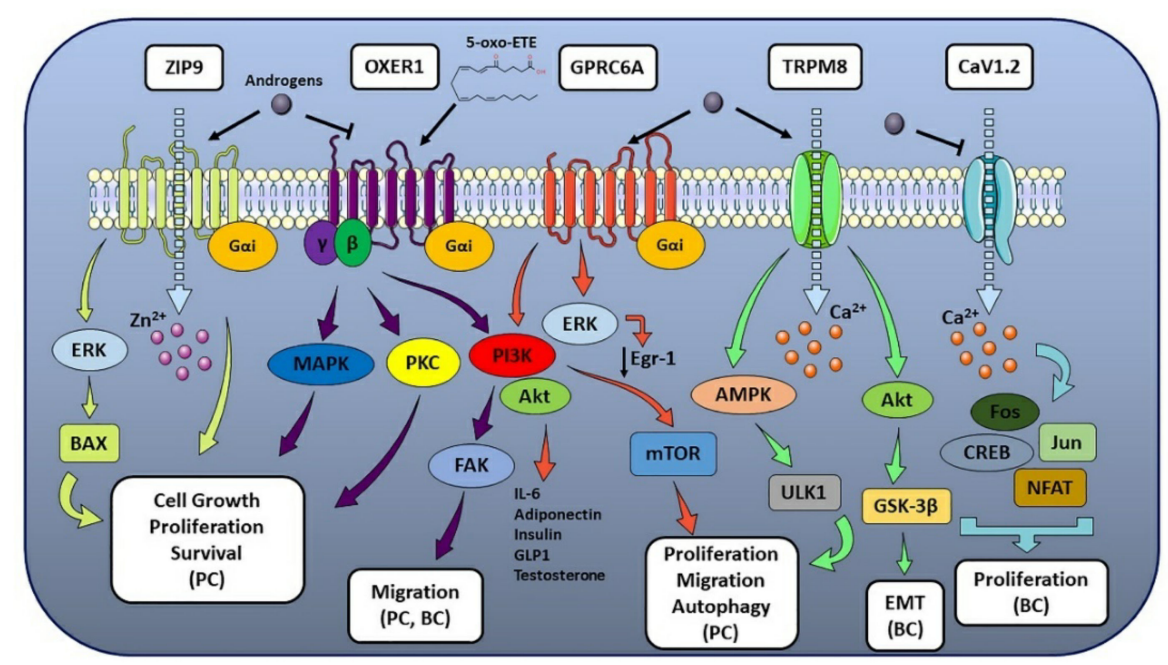

Figure 1. mAR-associated pathways and their effect on hormone-sensitive cancer progression. The figure illustrates the molecular pathways correlated to the different mARs and their biological effects on multiple hormone-sensitive cancer types. When one or more tumor-related processes were reported only for a specific cancer type, the latter was made explicit in the figure and put in parentheses (e.g., breast cancer as BC, prostate cancer as PC) (see text for details).

\subsubsection{OXER1}

OXER1 (previously known as G Protein-coupled Receptor 170 (GPR170), hGPCR48, HGPCR48, TG1019 or R527) is a G protein-coupled receptor (GPCR) coupled to a G $\alpha \mathrm{i}$ [21] and activated by 5-oxoeicosatretraenoic acid (5-oxo-ETE), 5-lipoxygenase (5-LOX) and peroxidase metabolite of arachidonic acid [22]. OXER1 mediates several intracellular actions, including steroidogenesis stimulation, immune and inflammatory responses, cell proliferation and survival [23]. Upon 5-oxo-ETE binding, OXER1 activation results in the G $\alpha$ i-mediated inhibition of cAMP production and $\mathrm{G} \beta \gamma$-mediated induction of $\mathrm{Ca}^{2+}$ mobilization, although $G \beta \gamma$ is responsible for mediating several other signaling path- 
ways [22,24]. These include chemotactic response and actin polymerization in different leukocyte types (e.g., neutrophils, eosinophils, and monocytes) [24,25], activation of PI3K and Akt (also known as Protein Kinase B, PKB), focal adhesion kinase (FAK), extracellular signal-regulated kinases 1/2 (ERK1/2), Phospholipase A2 (PLA2) and modulation of different Protein Kinase C (PKC) isoforms [26,27]. Most of these pathways are involved, even in different cellular contexts, in proinflammatory responses, infiltration and cell migration [9]. Despite the fact that most literature data are focused on OXER1 role in immune context, their role in the progression of different hormone-related cancers has also been investigated. Literature data confirmed that OXER1 is highly expressed in cancer cells and tissues, including prostate and breast $[28,29]$, where it has been observed to mediate survivalpromoting effects and inhibition of cell apoptosis, when activated by its endogenous ligand 5-oxo-ETE [23,29]. Cancer cells display high levels of 5-hydroxy-eicosatetraenoic acid dehydrogenase (5-HEDH) that can convert inflammatory cell-derived 5-hydroxyeicosatetraenoic acid (5S-HETE) to 5-oxo-ETE, especially when the cells are stressed [30]. 5-oxo-ETE produced within the tumor microenvironment (TME) can support OXER1-mediated cancer cell growth and promote further infiltration of inflammatory cells. Both prostate cancer-derived cell lines and prostate cancer tissue from patients contain high levels of OXER1 at both mRNA and protein levels $[23,29]$. In addition, membrane staining for OXER1 has been found to be significantly increased in prostate cancerous tissues compared to non-cancerous ones [18], supporting OXER1's role in prostate cancer cell growth and metastasis [23,31]. Indeed, OXER1 mediates cell proliferation, survival-promoting effects, and inhibition of cell apoptosis in prostate cancer cells, as well as adhesion, migration and invasion through its major signaling pathways involving p38 $\alpha$, PI3K/Akt and FAK [31]. OXER1 has also been identified as a specific $\mathrm{mAR}$, and testosterone acts as an antagonist on OXER1-mediated PI3K, FAK and p38 $\alpha$ signaling pathways, resulting in the inhibition of cell migration and metastasis [31,32] (Figure 1). OXER1 can also mediate androgen actions that antagonize the effects of 5-oxo-ETE, providing a novel link between steroid and lipid actions and an interesting target for therapeutic intervention [31]. In addition, since rapid androgen actions have been reported in classical AR-lacking breast cancer models [33] and membrane androgen binding sites have been observed in breast carcinoma cells [34], OXER1 has been recently proposed as a potential drug target in breast cancer [35]. Indeed, OXER1 role in malignant cell growth was firstly reported in MDA-MB-231 and MCF-7 breast cancer cell lines [28], which express high levels of OXER1 protein [18]. In agreement, inhibition of 5-oxo-ETE production by blocking 12-LOX and 5-LOX results in reduced proliferation and induced cytotoxicity and apoptosis, further supporting OXER1 role in breast cancer [36,37]. Data mining analysis also reveals that high OXER1 expression in tumor breast invasive carcinoma (TCGA-1097) correlates with a worse overall survival probability [38]. In addition, a recent study based on RNA-sequencing data proposed OXER1 as a key gene and possible molecular marker of tumorigenesis of Hormone-Receptor-positive/Human Epidermal Growth Factor Receptor 2 (also known as Receptor Tyrosine-Protein Kinase erbB-2, cluster of differentiation 340 (CD340), or proto-oncogene Neu)-negative (HR(+)/HER2(-)) breast cancer in adolescents and young adults [39].

\subsubsection{GPRC6A}

GPRC6A is a $\mathrm{Ca}^{2+}$ and amino acid sensing GPCR (widely expressed both in humans and in rodents) whose activity has been linked to rapid, non-genomic signaling responses exerted by androgens [40]. This receptor is involved in different physiological and pathological contexts, including male fertility, insulin secretion, bone and energy metabolism, inflammatory responses, and androgen production [9]. GPRC6A is coupled to a Gai protein and has been proposed to be a multi-sensing receptor, since its activation can be induced by $\mathrm{Ca}^{2+}, \mathrm{Mg}^{2+}$, osteocalcin, steroid hormones, and a variety of amino acids [40]. In this regard, GPRC6A has been demonstrated to mediate rapid and non-genomic signaling in response to androgen binding in AR-lacking cells, when overexpressed in these cellular models, while its silencing impaired exogenous androgen response [40]. As for the ability of this 
receptor to bind androgens, both computational analyses and in vitro assays demonstrated that testosterone can bind GPRC6A, leading to ERK1/2 phosphorylation and activation and to a decrease in tumor-suppressor Early Growth Response Protein 1 (Egr-1, also known as Zinc Finger protein 268, ZNF268, or Nerve Growth Factor-Induced protein A, NGFI-A) [40]. In addition, GPRC6A activation in different tissues led to the production of different cytokines (including IL-6 and adiponectin) and hormones (insulin, Glucagon-Like Peptide 1 (GLP-1) and testosterone) [40]. Noteworthy, compared to normal prostate cells, GPRC6A upregulation was observed in different prostate cancer cell lines, where its activation led to an increase in chemotaxis and cell proliferation in vitro [40]. Conversely, ablation of GPRC6A in prostate cancer mice xenografts resulted in decreased tumor progression and enhanced survival [41]. Indeed, testosterone binding to GPRC6A has been demonstrated to activate ERK, Akt and mammalian Target of Rapamycin (mTOR) signaling pathways in a time and dose-dependent manner, resulting in an increased cell proliferation and inhibition of autophagy in prostate cancer cells [42] (Figure 1). Noteworthy, the association between GPRC6A gene and prostate cancer risk has been widely reported in Eastern Asian populations [43-45], and the rs2274911 polymorphism in GPRC6A has been associated with increased risk of prostate cancer, since this mutation promotes prostate cancer cell proliferation and is associated with increased prostate-specific antigen (PSA) serum levels [46]. In addition, clinical and in vitro data revealed that GPRC6A is associated with aggressive prostate cancer, with a pivotal role in cell proliferation, migration, invasion, and Epithelial-Mesenchymal Transition (EMT) [47].

\subsubsection{TRPM8}

TRPM8 (also known as the Cold and Menthol Receptor 1, CMR1) is an androgenregulated, $\mathrm{Ca}^{2+}$-selective cation channel sensitive to cold physical stimulus, menthol and icilin (AG-3-5), located at the endoplasmic reticulum and plasma membranes of androgenresponsive cells [9]. Indeed, TRPM8 has been recognized as an androgen-related receptor due to its androgen binding affinity and steroid specificity [48], and this strong binding of androgens, such as testosterone and DHT, affects its $\mathrm{Ca}^{2+}$ channeling activity [49]. TRPM8 is widely expressed in different tissues, including hepatic and intestinal tissues, peripheral nervous system, male urogenital tract, and cancer tissues [50]. Indeed, TRPM8 is involved in the regulation of several key processes, including inflammatory and immunomodulatory responses, cell proliferation, migration, and apoptosis [51]. In this regard, TRPM8 is a possible prostate cancer biomarker $[52,53]$ reported to be significantly increased in earlystage prostate cancer, while its expression is significantly decreased in advanced stages androgen-independent prostate tumors [54]. Moreover, TRPM8 is highly expressed in the prostate epithelium, its levels rise in primary and hormone naïve prostate cancer metastasis [55], and several clinical data report TRPM8 among other candidate gene markers for metastatic prostate [56,57] and TRPM8 mRNA levels were found significantly upregulated in prostate cancer samples [58] and correlated with those of kallikrein-3 (KLK3, also known as PSA, gamma-seminoprotein or P-30 antigen) [59]. Although restricted to a limited number of studies, TRPM8 involvement in tumor progression has also been investigated in breast cancer since it was found overexpressed in human Breast Ductal Adenocarcinoma (hBDA) samples [60]. In this regard, TRPM8 has been reported to activate Akt and Glycogen Synthase Kinase 3 beta (GSK-3 $\beta$ ) pathway to promote EMT and breast cancer aggressiveness [61] and to regulate proliferation, migration, and autophagy by activating AMP-Activated Protein Kinase (AMPK) and Unc-51 Like Autophagy Activating Kinase (ULK1) pathway [62] (Figure 1). Furthermore, in vitro and clinical data support the role of TRPM8 as a biomarker for poor clinical outcome prediction in estrogen receptor (ER)-negative breast cancer patients $[63,64]$.

\subsubsection{CaV1.2}

CaV1.2 is a member of the L-type Voltage-Gated $\mathrm{Ca}^{2+}$ Channel (VGCC) family (CaV1.1CaV1.4), known to play pivotal roles in the regulation of $\mathrm{Ca}^{2+}$ homeostasis, secretion, and 
tissue development. L-type VGCC are multi-subunit channels formed by three distinct proteins, namely, $\mathrm{CaV} \alpha 1, \mathrm{CaV} \alpha 2 \delta$ and $\mathrm{CaV} \beta$ [65]. The ion-conducting channel is formed by the four $\mathrm{CaV} \alpha 1$ subunits, which have multiple splice variants that confer their pleiotropic effects and their association with a wide range of pathologies, including cancer [65]. Noteworthy, an increased intracellular $\mathrm{Ca}^{2+}$ influx induced by $\mathrm{CaV} 1.2$ can lead to the activation of Nuclear Factor of Activated T cells (NFAT) via calcineurin-mediated dephosphorylation and nuclear translocation [66,67]. In this regard, increased NFAT transcriptional activity has been implicated with increased cancer progression events, including proliferation, migration, invasion, autophagy, and tumor neo-angiogenesis $[67,68]$. Cav1.2-mediated $\mathrm{Ca}^{2+}$ influx has been associated with the activation of transcription factors Fos; c-Jun; cAMP Response Element-Binding protein (CREB); NFAT; and the expression of D-cyclins to control G1/S transition and, thus, cell proliferation [69,70] (Figure 1). Interestingly, not only testosterone has been demonstrated to bind and inhibit CaV1.2-induced $\mathrm{Ca}^{2+}$ influx [71] but also $5 \alpha$-dihydrotestosterone decreased CaV1.2 expression in the luminal breast cancer MCF-7 cells, affecting their viability and proliferation [70].

\subsection{Membrane Estrogen Receptors}

nSRs, known as estrogen receptors alpha and beta (ER $\alpha$ and ER $\beta$ ), are the most characterized and well-studied receptors known to exert the effects of endogenous and exogenous estrogens, estrogen-like substances and xenoestrogens. However, other molecular mediators of estrogenic action are located at the cellular plasma membrane and include G-Protein Estrogen Receptor (GPER), ERx, ER-X and Gq-coupled membrane Estrogen Receptor (Gq$\mathrm{mER}$ [ [72]. In addition, Voltage-Gated Sodium Channel Nav1.2 is also reported to bind estrogens and to activate molecular cascades upon their binding [10].

\subsubsection{GPER}

While for ER-X and Gq-mER there are almost no literature data on their possible role in cancer progression [73], and for ERx available data are limited to in vitro observations regarding breast cancer [74], GPER (previously known as G Protein-coupled Receptor 30, GPR30) has been associated to the modulation of signaling pathways involved in tumor growth both in vitro and in vivo $[75,76]$. GPER is a 7TM receptor coupled to G protein (encoded by GPER gene in humans) capable of binding endogenous estradiol (E2) with high affinity and responsible for the activation of rapid, non-genomic estrogenic effects [77]. GPER is a member of the Rhodopsin-like GPCR family mainly localized at the cellular plasma membrane, where it has been shown to signal through the activation of both G $\alpha \mathrm{s}$ and $\mathrm{G} \alpha \mathrm{i}[78,79]$. Its activation results in the induction of $\mathrm{Ca}^{2+}$ mobilization and synthesis of phosphatidylinositol $(3,4,5)$-trisphosphate (PIP3), and several studies provided evidence of GPER localization also in intracellular compartments, including the endoplasmic reticulum, Golgi apparatus and nucleus [80]. However, its distribution appears to vary depending on species, tissue, and cell type and to dynamically change in response to specific environmental signals. GPER is expressed in different tissues, including breast, prostate, and ovary, as well as in immune cells [81,82], and its expression is suggested to be species-, gender-, tissue- and age-dependent [83]. In addition, GPER abundance has been reported to be developmentally regulated, since its expression in elongating ducts of the mammary gland not only is lower during puberty and increases during sexual maturity but also appears to be dependent on estrous cycle [78]. These findings are of pivotal interest not only in the investigation of GPER physiological function but also for its pathologic role in different contexts, including metabolic functions, reproduction, immune regulation, and cancer development and progression [82,84]. GPER expression has been associated with metastasis formation, tumor size and recurrence in both breast and ovarian cancer [85], and with the expression of a gene signature involved in the metastasis of ER-negative breast tumors [86]. In addition, GPER activation has been observed to play a critical role in breast cancer growth, proliferation, migration, and metastasis [76] via the modulation of different molecular pathways. These include the stabilization of the F-actin cytoskeleton and the 
upregulation of Yes-Associated Protein 1 (YAP) and Transcriptional coactivator with a PDZbinding domain (TAZ) via the activation of G $\alpha q-11$, Phospholipase C beta (PLC $\beta$ )/PKC and Rho/Rho-associated protein kinase (ROCK) signaling [87,88]; the downregulation of microRNA-124 (miR124) and miR-148a to promote proliferation and support immune invasion via the upregulation of CD151, HOX Transcript Antisense RNA (HOTAIR) and Histocompatibility Antigen, class I, G (HLA-G) [89-91]; the enhancement of Fibronectin (FN) matrix assembly and anchorage-independent growth [92]; and cell survival through the activation of epidermal growth factor receptor (EGFR)/ERK/c-Fos / Activator Protein 1 (AP-1) for Sirtuin 1 (SIRT1, also known as NAD-dependent deacetylase sirtuin-1) upregulation [93], MAPK/ERK/Tripartite Motif Containing 2 (TRIM-2) for Bcl-2-like protein 11 (BIM) downregulation [94], and EGFR/PI3K for Forkhead Box O3s (FOXO3a) inhibition [95]. Moreover, GPER appears to be required for stemness maintenance in cancer stem cells via PKA/Bcl-2 associated agonist of cell death (BAD) pathway [96] and the development of chemoresistance via EGFR/ERK/Akt-mediated ATP Binding Cassette, Subfamily G, Member 2 (ABCG2) expression [97]. This is in line with the increasing evidence that GPER expression and activation is correlated with a poor response to chemotherapy with selective estrogen receptor modulators $[98,99]$. However, GPER role in breast cancer still needs to be fully clarified due to contrasting literature data on its significance as prognosis predictor [100-102]. This could be attributed not only to the variation of GPER expression during carcinogenesis due to the progressive hypermethylation of its promoter [103] but also to GPER different role depending on the specific breast cancer context.

Clinical data reported a correlation between GPER expression and poor prognosis also in other female reproductive cancers [104]. GPER has been proposed to act as tumor suppressor in ovarian cancer [105] and to have, together with Wnt pathway modulator Dickkopf 2 (Dkk2) expression, a positive prognostic impact in ovarian cancer patients [106,107]. GPER not only suppresses the proliferation of ovarian cancer cells by blocking tubulin polymerization $[108,109]$, but its activation also led to a transcriptome response associated with growth inhibition in ovarian cancer cells [110] and triggered a ERK1/2-mediated trimethylation of Histone $\mathrm{H} 3$ at Lysine 4 (H3K4me3) to repress migration and proliferation in vitro [111]. However, contrasting evidence supports the role of GPER in mediating proliferation, migration, and invasion in vitro-through the expression of c-Fos, cyclin D1, Matrix Metallopeptidase 2 (MMP2, also known as gelatinase A, GELA or $72 \mathrm{kDa}$ type IV collagenase) and MMP9 9 (also known as gelatinase B, GELB) — in both an E2-mediated [112,113] and a ligand-independent manner [114]. In endometrial cancer, GPER has been observed to promote cell proliferation by enhancing the expression of aromatase, nuclear hormone receptors Steroidogenic Factor 1 (SF-1) and Liver Receptor Homolog-1 (LRH-1) via a PI3K/Akt- and MAPK-mediated mechanism [115], and through a GPER/EGFR/ERK/Egr1 transduction pathway resulting in the expression of cyclin D1 and Connective Tissue Growth Factor (CTGF, also known as CCN2) [116]. Moreover, upon E2 binding, GPER also regulates in vitro endometrial cancer cells motility and anchorage-independent growth through Diacylglycerol Kinase alpha (DGK $\alpha)$ [117]. GPER pro-tumorigenic role in endometrial cancer is also supported by evidence reporting anti-EMT effects by GPER targeting via miR-195 [118] and cell proliferation via miR-424 [119].

GPER tumorigenic properties have also been investigated in male cancers, namely, prostate and testicular cancers. Indeed, GPER activation led to the ERK1/2-mediated inhibition of prostate cancer cell growth [120], although its role and significance still need to be completely elucidated. Finally, GPER is also involved in regulating the proliferation of testicular germ cell cancer [121,122] and has been reported to be overexpressed in human seminoma (a testicular germ cell tumor subtype) [122]. Indeed, clinical and experimental studies support the hypothesis that estrogens, through GPER activity, contribute to the regulation of tumor testicular germ cells proliferation via ERK1/2 [121,122]. Noteworthy, two polymorphisms in the promoter region of GPER (rs3808350 and rs3808351) in seminomas are correlated to its overexpression and confer genetic susceptibility for testicular carcinogenesis [122]. Conversely, in Leydig cell tumor (a different testicular germ cell 
tumor subtype compared to seminoma), GPER activation is correlated with decreased proliferation, increased apoptosis [121] and perturbance of lipid metabolism and steroidogenesis via PI3K/Akt/mTOR pathway impairment [123], suggesting that, for testicular germ cell tumors, GPER-mediated effects on cell survival and proliferation depend on specific cell type (Figure 2).

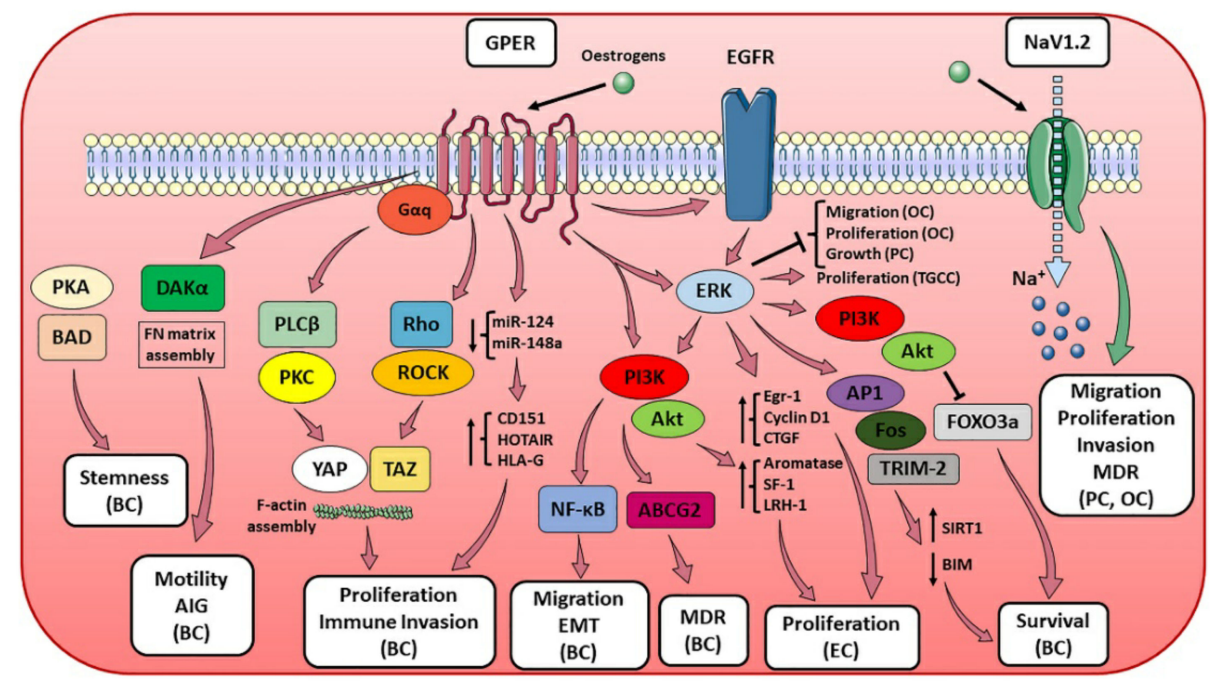

Figure 2. mER-associated pathways and their effect on hormone-sensitive cancer progression. The figure illustrates the molecular pathways correlated to the different mERs and their biological effects on multiple hormone-sensitive cancer types. When one or more tumor-related processes were reported only for a specific cancer type, the latter was made explicit in the figure and put in parentheses (e.g., breast cancer as BC, prostate cancer as PC, endometrial cancer as EC, ovarian cancer as OC and testicular germ cell cancer as TGCC). Other abbreviations: multi-drug resistance (MDR), anchorage-independent growth (AIG) (see text for details).

\subsubsection{NaV1.2}

Voltage-Gated Sodium Channels (VGSCs) are integral membrane glycoprotein complexes that, in response to membrane potential depolarization, undergo a conformational change, open a transmembrane pore and mediate a $\mathrm{Na}^{+}$influx. VGSCs are composed of principal subunits alpha (VGSC $\alpha$ ) and auxiliary subunits beta (VGSC $\beta$ ), and, since they are functionally expressed in different tissues and cell types [124], VGSCs are involved in a variety of molecular events, including neurotransmission, nerve skeletal and cardiac muscle contraction, and secretion. In this regard, VGSCs play an important role in the development and progression of different cancers, since they have been correlated with different events of the carcinogenic process, including cell proliferation, migration, invasion, and Multi-Drug Resistance (MDR) [125,126]. NaV1.2 channel increased expression has been observed in different cancer types, including prostate [127] and ovarian cancer, where it is involved in regulating migration and invasion of highly metastatic cancer cells [128]. Interestingly, rapid estrogen actions on different ion channels' functionality have been reported, and both endogenous and exogenous estrogens can bind NaV1.2, other VGSCs and other ion channels, to regulate their activity [129,130] (Figure 2).

\subsection{Membrane Progesterone Receptors}

In the same way for androgen and estrogen signaling, the progesterone receptor (PR), with its two isoforms PR-A and PR-B, is the most prominent and studied mediator of progestogenic effects, although other receptors localized at the plasma membrane level can participate in mediating progesterone (P4) and progesterone-like substances effects. These membrane progesterone receptors that mediate non-traditional progesterone actions are classified into two groups: the class II progestin and adipoQ receptor (PAQR) 
family (also called membrane Progesterone Receptors, mPRs) includes $m P R \alpha, \operatorname{mPR} \beta$, $\mathrm{mPR} \gamma, \mathrm{mPR} \delta, \mathrm{mPR} \varepsilon$ encoded by PAQR7, PAQR8, PAQR5, PAQR6 and PAQR9 genes, respectively [131], while the b5-like haem/steroid-binding protein family (also called Membrane Associated Progesterone Receptors, MAPRs) comprises Progesterone Receptor Membrane Component 1 (PGRMC1), PGRMC2, GIG47 (previously known as NeuronDerived Neurotrophic Factor, NENF, and neudesin) and neuferricin (alternatively termed Cytochrome B5 Domain Containing 2, CYB5D2) [132].

\subsection{1. mPRs}

The mPRs are 7-transmembrane protein receptors located in the cell plasma membrane that transduce via G-proteins, even though they do not share structural nor sequence homology to GPCRs and nuclear steroid receptors [131]. In mammals, these receptors show a differential expression in both reproductive (e.g., ovary, uterus, placenta, and testis) and non-reproductive (e.g., brain, kidney and intestinal) tissues [133] and display a high binding affinity for progestins. Although several members of the class II PAQR family are known, most literature data reported and focused on the functional characterization of $\mathrm{mPR} \alpha$, which is the most abundant $\mathrm{mPR}$ expressed in different human tissues [134], while information is still lacking for the other members. Several studies reported that $\mathrm{mPR} \alpha$, $\mathrm{mPR} \beta$ and $\mathrm{mPR} \gamma$ are coupled and activate a G $\alpha \mathrm{i}$, leading to a progestin-triggered downregulation of adenylyl cyclase activity $[131,134]$, while $\mathrm{mPR} \delta$ and $\mathrm{mPR} \varepsilon$ have been shown to

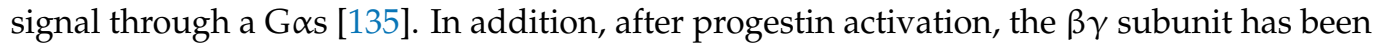
reported to participate in signal transduction by upregulating PI3K/Akt, ERK1/2 and p38 MAPK molecular pathways [136]. Progestin functions correlated to the presence of mPRs and mPR-dependent signaling in mammalian cells have been suggested to mediate the development of breast and ovarian hormone-sensitive cancers $[137,138]$ since $\mathrm{P} 4$ has been observed to inhibit the EMT process in breast cancer cells through mPRs-mediated PI3K and EGFR activation [139] and to transduce through mPRs in ovarian cancer cells [140]. Regarding breast cancer, $\mathrm{mPR} \alpha$ and MMP9 expression and Akt phosphorylation have been reported to be higher in breast cancer tissue compared to non-cancerous one. A positive correlation between $\mathrm{mPR} \alpha, \mathrm{HER} 2$ and MMP9 expression and tumor size has been reported, while a negative correlation with ER and PR status has also been observed [141]. In addition, $\mathrm{mPR} \alpha$ expression also showed a positive correlation with EGFR, HER2 and Ki67 expression pattern [142]. Indeed, P4-mediated $\mathrm{mPR} \alpha$ activation has been found to modulate cell proliferation via PI3K molecular pathway [142]; to decrease apoptosis; to increase mitochondrial potential through G $\alpha \mathrm{i}, \mathrm{p} 42 / 44 \mathrm{MAPK}$ and Akt signaling cascades [143]; and to upregulate the breast cancer resistance protein (BCRP) —an independent risk factor for breast cancer and possible marker for poor prognosis-through PI3K/Akt/mTOR pathway [144], supporting a role for $\mathrm{mPR} \alpha$ in the development and progression of breast cancer through cell death inhibition and its role as a major prognostic marker of poor prognosis (Figure 3). Conversely, upon its $\mathrm{P} 4$-mediated activation, $\mathrm{mPR} \alpha$ exerts inhibitory effects on cell proliferation and migration in triple-negative breast cancer [145] and in basal phenotype breast cancer via FAK dephosphorylation, MMP9, Vascular-Endothelial Growth Factor (VEGF), and Calcium-Activated Potassium Channel Subunit alpha-1 (KCNMA1, also known as BK channel alpha subunit or large conductance $\mathrm{Ca}^{2+}$-activated potassium channel, subfamily M, alpha member 1, KCa1.1) downregulation mechanisms [146]. Regarding ovarian cancer, expression profiles of $\mathrm{mPR} \alpha$ and $\mathrm{mPR} \beta$ suggested a potential role in the pathogenesis and development of ovarian tumors [147]. However, unlike in breast cancer cells, P4-triggered MPR activity has been shown to indirectly induce cAMP levels by enhancing $\beta 1,2$-adrenergic receptor activation and to up-regulate apoptosis regulator BAX (also known as Bcl-2-like protein 4) through JNK1/2 and p38 MAPKs activation [148], indicating the existence of mPR-induced molecular pathway that, through pro-apoptotic MAPK signaling modules, can lead to ovarian cancer cell death and suggesting that P4based hormone therapy could provide a suitable and effective strategy for the treatment of ovarian cancer [148] (Figure 3). In addition to breast and ovarian cancers, mPR have been 
associated also with other hormone-sensitive tumors like endometrial and prostate cancers. Indeed, analyses of samples of endometrial cancer patients not only revealed that mPR $\beta$ and $\mathrm{mPR} \gamma$ displayed a different subcellular localization in cancerous tissue compared to non-cancerous one but also suggest, based on expression data, these receptors as potential prognostic biomarker for endometrial cancer [149]. Regarding prostate cancer, mRNA expression analyses of samples from patients revealed that PAQR6 levels were upregulated compared to non-cancerous tissue and positively correlated with a lower survival rate. In addition, gene silencing data correlated $\mathrm{mPR} \delta$ activity with MEK and ERK1/2 signaling pathway involved in proliferation and migration of tumor cells, suggesting its potential role in prostate cancer development and serving as potential prognosis biomarker [150] (Figure 3).

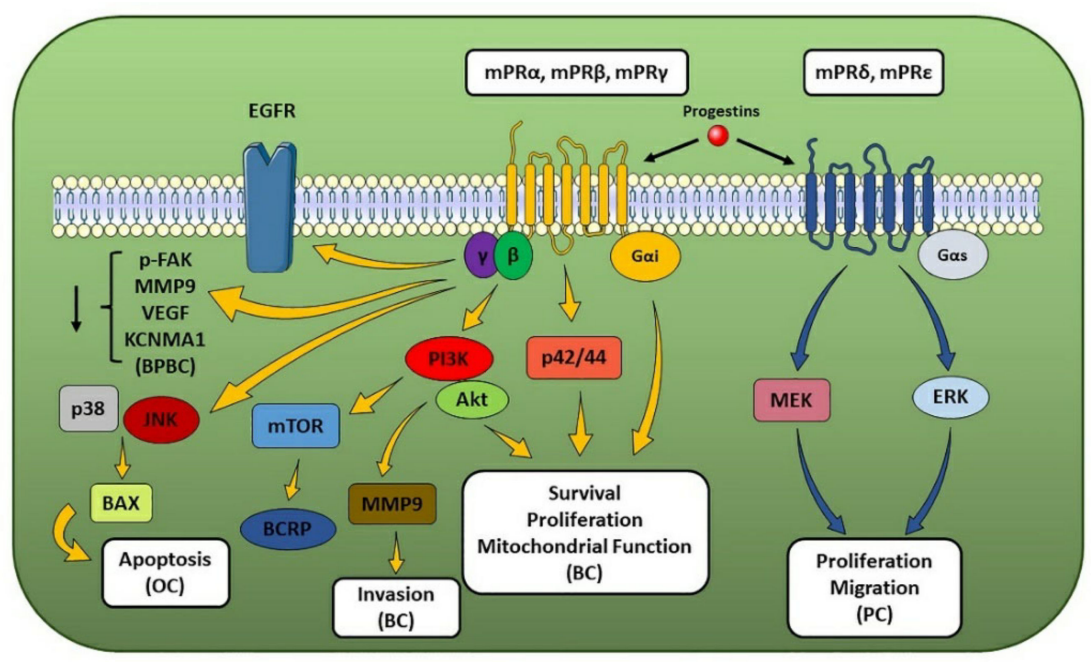

Figure 3. mPR-associated pathways and their effect on hormone-sensitive cancer progression. The figure illustrates the molecular pathways correlated to the different mPRs and their biological effects on multiple hormone-sensitive cancer types. When one or more tumor-related processes were reported only for a specific cancer type, the latter has been made explicit in the figure and put in parentheses (e.g., breast cancer as BC, prostate cancer as PC, ovarian cancer as OC, and basal phenotype breast cancer as BPBC) (see text for details).

\subsubsection{MAPRs}

MAPRs proteins, like mPRs, are membrane-bound receptors-evolutionarily conserved and distant homologues of the small haemoprotein Cytochrome B5 (CYB5)_able to bind P4 and activate rapid, non-genomic and PR-independent effects. MAPRs can interact with the superfamily of microsomal and mitochondrial haemoproteins Cytochrome P450 enzymes (CYP) and other different proteins to regulate a variety of molecular processes, including cell proliferation and migration, steroid homeostasis, and autophagy [132].

PGRMC1 features a single transmembrane domain and, besides progestins, binds several other ligands, including cholesterol, glucocorticoids, and other steroids [134]. It is localized, together with CYPs, in different subcellular compartments, including the plasma membrane, nucleus, endoplasmic reticulum and mitochondria [151]. Its expression is upregulated in different tumor types, and it is involved in promoting cancer progression and EMT $[152,153]$. This is in line with the reported role of PGRMC1 in promoting cell self-renewal and inhibiting differentiation by downregulating Wnt/ $\beta$-catenin and p53 pathways [154], as well as upregulating energy metabolism, mitochondrial function, glycolysis, cell motility and tumor growth, through PI3K/Akt pathway [155]. Regarding hormone-sensitive cancers, PGRMC1 has been shown to regulate some breast cancer hallmarks [156]. Indeed, PGRMC1 can promote tumorigenesis [157], and its expression is associated with a malignant breast cancer phenotype [158]. Recently, independent studies showed a positive correlation between PGRMC1 expression levels and breast features 
associated with poor prognosis $[159,160]$, further suggesting its role as tumor marker and strengthening PGRMC1 prognostic value for this malignancy. PGRMC1 can promote breast cancer development by increasing survival and growth of tumor cells [161] and inducing neovascularization in tumor tissue through VEGF activation [162]. These observations on its tumor-promoting role were confirmed by the reduced migration and metastasis of breast cancer cells after PGRMC1 knock-out [163] and by the suppression effect on PGRMC1 tumorigenicity exerted by miR-181a [164]. At molecular level, although conflicting data are reported in literature regarding PGRMC1-initiated effects in breast cancer cells [165], PGRMC1 activation enhances PI3K/Akt/mTOR and EGFR-mediated signaling pathways, resulting in the increased proliferation [166] and alteration of lipid metabolism [167] in ER+ and triple-negative breast tumors. This is in line with the reported association between PGRMC1 and ER levels [160], the observed PGRMC1-mediated ER $\alpha$ activation [167] and the increased breast cancer cell proliferation correlated with PGRMC1-ER $\alpha$ crosstalk recently reported [168]. However, PGRMC1's role in tumor development and progression is not limited to breast cancer. Indeed, several studies reported its involvement also in other hormone-sensitive cancers, including testicular Leydig cell tumor proliferation and invasion through Transforming Growth Factor beta (TGF- $\beta$ ) alternative pathway [169], endometrial cancer [170] and ovarian cancer, in which PGRMC1 activation promotes cell viability, growth, proliferation, migration and survival through PI3K/Akt-mediated inhibition of apoptosis [171,172] (Figure 4).

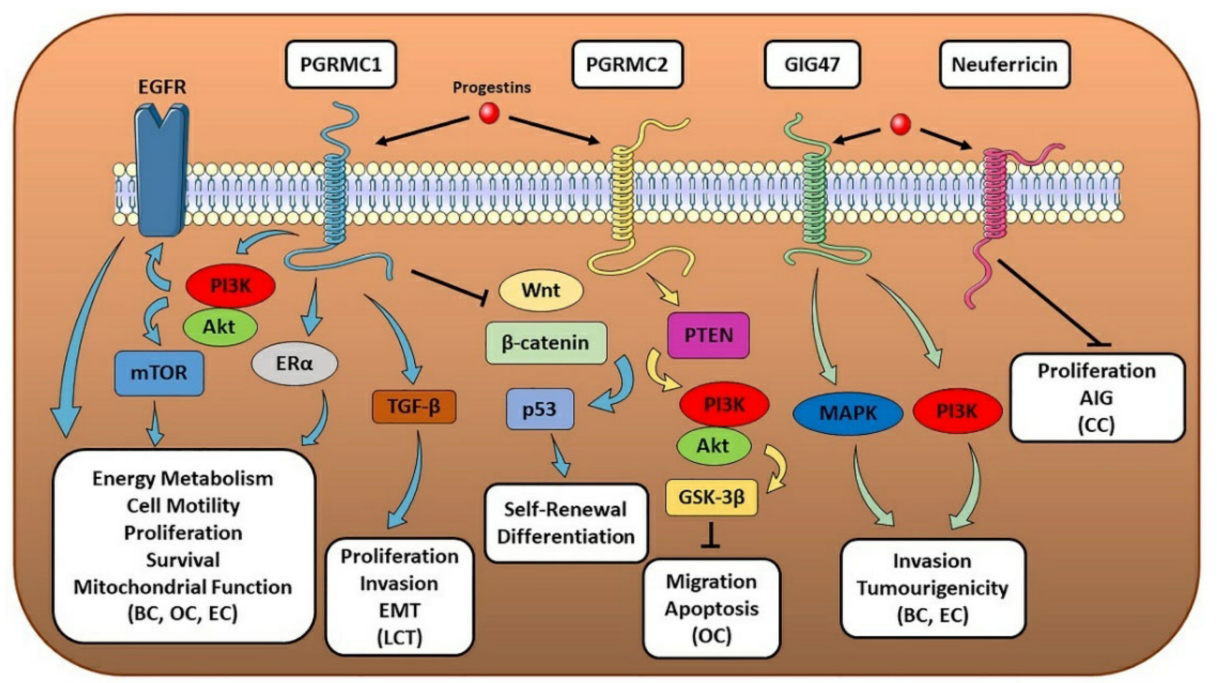

Figure 4. MAPR-associated pathways and their effect on hormone-sensitive cancer progression. The figure illustrates the molecular pathways correlated to the different MAPRs and their biological effects on multiple hormone-sensitive cancer types. When one or more tumor-related processes were reported only for a specific cancer type, the latter has been made explicit in the figure and put in parentheses (e.g., breast cancer as BC, endometrial cancer as EC, ovarian cancer as OC, Leydig cell tumor as LCT and cervical cancer as CC). Other abbreviations: anchorage-independent growth (AIG) (see text for details).

PGRMC2 is a membrane-bound receptor structurally similar to PGRMC1, although it displays a different N-terminal transmembrane domain and is less functionally characterized [173]. Like PGRMC1, PGRMC2 is expressed in different tissues and with a similar subcellular localization. Although limited studies on its role in cancer development and progression are available, PGRMC2 expression, which has been shown to be post-transcriptionally regulated by miR-142-3p [174], is higher in breast cancer tissue compared to non-cancerous one, suggesting its potential contribution to the tumorigenesis of the breast [175] and serving as possible biomarker for breast cancer staging [176]. Moreover, PGRMC2 is highly expressed in ovarian cancer cells, and in vitro studies showed that its P4-mediated activation resulted in the inhi- 
bition of cell migration [177] and apoptosis through PI3K/Phosphatase and Tensin Homolog (PTEN)/Akt/GSK-3 $\beta$ axis [172] (Figure 4).

Although originally identified as a secreted protein with neurotrophic actions mediated via MAPK and PI3K pathways, Nuclear Magnetic Resonance (NMR) studies revealed that GIG47 shares a similar structure with PGRMC1 and 2 [178]. GIG47 increased expression has been reported in several cancer types, including uterine and breast cancer, in which it promotes cancer cell invasion and increased tumorigenicity through MAPK and PI3K pathways [178] (Figure 4). In addition to its receptor-correlated activity, an extracellularly secreted GIG47 has been shown to be involved in cancer cell immortalization and resistance to carcinogens [179].

A homology-based search of the same CYB5-like haem/steroid-binding domain of PGRMC1, PGRMC2 and GIG47 led to the discovery of Neuferricin that, like the other MAPRs, is expressed in a variety of different tissues [132]. Like GIG47, Neuferricin can be detected as both secreted haemoprotein and membrane-bound receptor, especially localized in the endoplasmic reticulum, where it can interact with CYP Reductase (POR) [180]. Its expression has been correlated with the inhibition of cell proliferation and anchorageindependent colony growth in vitro in cervical cancer cells [180] and has been suggested as a potential candidate tumor suppressor of cervical tumorigenesis [181]. However, correlations between Neuferricin expression or its activity and the development and progression of hormone-sensitive cancers have not been found yet.

\section{Beyond mSRs Physiologic Role}

Since the mSRs reported and dissected here show widespread expression in human tissues and can regulate the activation of well-known and pivotal signaling pathways, the exposure to exogenous hormone-active substances, e.g., EDCs, can cause their aberrant and non-physiologic activation. This can trigger different molecular mechanisms and initiate a variety of pleiotropic effects that, due to the uncertainty about time, duration, and concentration of exposure, may play a role in the development and progression of different diseases that rely on the activity of hormones and hormone-like compounds. Therefore, in a hormone-sensitive cancer context, $\mathrm{mSR}$ abnormal activation in different but adjacent tissues may shape the characteristics of the TME to drive and sustain the formation of the cancer mass [3]. On the other hand, this ability to affect not only cancer cells but also other cellular subpopulations within the TME, including immune cells, makes mSRs possible and interesting drug targets able to interfere not only with the biology of cancer cells but also with cancer-promoting and cancer-sustaining mechanisms activated by other adjacent cell types. In the following section, the role of different mSRs will be firstly dissected as possible TME shapers due to their role as EDCs receptors and, secondly, as potential drug targets for different hormone-sensitive cancers.

\section{1. $m S R$ s as EDCs Targets}

In the classic definition of endocrine disruption, hormonally active agents are considered for their ability to interfere with the action of hormones and endocrine signaling primarily through nSRs. Noteworthy, EDCs have been shown to affect hormone signaling within the TME to promote a crosstalk between cancers cells, stromal cells, and immune cells and to influence the extracellular matrix remodeling in a pro-tumorigenic manner, finally contributing to cancer cell progression, invasion, and metastasis formation (reviewed in [3]). However, recent and increasing evidence suggests that also mSRs should be considered in the mechanism of endocrine disruption since EDCs have been shown to bind and modulate mSR-initiated downstream molecular processes.

Regarding mARs, in prostate cancer cells, a variety of pesticides, including prochloraz, vinclozolin and its metabolite M2 (3',5'-dichloro-2-hydroxy-2-methylbut-3-enanilide), have been shown to exert antiandrogen actions through ZIP9, competing with testosterone and antagonising ERK-mediated pro-apoptotic gene BAX expression and reducing ZIPmediated intracellular free $\mathrm{Zn}^{2+}$ influx [182]. However, potential adverse effects on human 
health as a consequence of the inhibition of ZIP9-dependent functions could include the attenuation of testosterone-activated pro-apoptotic and antitumorigenic effects in prostate cancer cells [9,12]. Moreover, in addition to environmental chemicals and pollutants, also plant-derived compounds have been shown to exert anti-androgenic and mAR-directed mechanism of endocrine disruption [32], although the roles of ZIP9, OXER1, and GPRC6A in mediating mechanisms of cancer progression activated by phyto-antiandrogens have still to be elucidated.

Among the different mERs, GPER is the most studied for its correlations with mechanisms of endocrine disruption $[183,184]$. In this regard, upon the binding of a variety of estrogen-active compounds-namely, diethylstilbestrol (DES), zearalenone (ZEA), bisphenols A, AF, B and S (BPA, BPAF, BPB and BPS), Tetrachlorobisphenol A (TCBPA) and Tetrabromobisphenol A (TBBPA) - GPER has been shown to enhance migration and proliferation of multiple breast cancer cell lines [185-190] by activating FAK, Src and ERK2 (via EGFR) to promote focal adhesion (FA) assembly [191]; to enhance cancer cell proliferation in testicular seminoma [192]; and, via PI3K/Akt/mTOR pathway, in Leydig cell tumor [193]; to induce, through a Receptor for Activated C Kinase 1 (RACK1)/PKC-dependent mechanism, an increased production of pro-inflammatory cytokines TNF- $\alpha$ and IL-8 in THP-1 cells, thus predisposing the cell to an increased response to pro-inflammatory stimuli [194-196]. These effects could be particularly relevant in shaping pivotal TME characteristics, since the misregulated and unhealthy Pro-tumor Inflammation (PTI), directly correlated with TNF- $\alpha$ and monocytes/macrophages action, has been shown to facilitate the oncogenic process by promoting tumor growth, survival and metastasis and to suppress the antitumoral immune response, leading to TME alterations [197]. In addition, 3-methylcholanthrene has been reported to activate EGFR/ERK/c-Fos transduction signaling through an Aryl hydrocarbon Receptor (AhR) and GPER-mediated mechanism in both breast cancer cells and Cancer-Associated Fibroblasts (CAFs). This activation led to the upregulation of cyclin D1 and CYP1B1 (an enzyme required for estrogen metabolism and oncogenic activation of environmental pollutants), which resulted in an increased tumor growth [198], further outlining GPER potential role in shaping the TME in a pro-tumorigenic manner.

On the other hand, literature data on MPR- and MAPR-related endocrine disruption mechanisms are still limited and uncertain. In this regard, in vitro analyses in MDAMB-231 breast cancer cells showed that DES and its analogues can bind and activate $\mathrm{mPR} \alpha$, thus mimicking non-genomic progestins action [199]. In addition, the activation of PGRMC1 triggered by ethynylestradiol (EE) and other estrogen-like compounds has been shown to induce and enhance breast cancer cell proliferation both in vitro and in xenograft [200,201], in line with the previous observation that PGRMC1 can promote breast cancer cell proliferation through an E2-induced mechanism [202].

\section{2. $m S R s$ as Drug Targets}

The ability to bind hormones and hormone-like substances and to activate nongenomic pathways with a pivotal role in cancer progression makes mSRs interesting and potential new drug targets for the development of structure-based compounds tailored to activate or antagonize one or more $\mathrm{mSR}$, depending on the receptor, the activated pathways and the hormone-sensitive cancer considered. In addition, the expression of the same mSR in different but strictly connected tissues in the TME also offers the possibility to intervene not only on the tumorigenic process itself but also in cancer-sustaining mechanisms. Synthetic and natural compounds able to bind mSRs here presented-apart from TRPM8 and GPER, whose molecular modulators were recently and excellently reviewed $[203,204]$-are listed in Table 1. 
Table 1. mSR-targeting compounds in pre-clinical studies and their correlated effects.

\begin{tabular}{|c|c|c|c|c|c|c|}
\hline Compound & Receptor & Profile & Cell Line/Model & Pathway & Effect & Ref. \\
\hline (-)-Epicatechin & ZIP9 & agonist & $\begin{array}{c}\text { PC3 (PC) } \\
\text { MDA-MB-468 (BC) }\end{array}$ & $\begin{array}{l}\text { ERK1/2, JNK and } \\
\text { Bax }\end{array}$ & $\begin{array}{l}\text { Proapoptotic action (increased } \\
\text { Caspase- } 3 \text { levels), increased cAMP and } \\
\text { intracellular } \mathrm{Zn}^{2+} \text { levels }\end{array}$ & [205] \\
\hline$(+)$-Catechin & ZIP9 & antagonist & $\begin{array}{c}\text { PC3 } \\
\text { MDA-MB-468 }\end{array}$ & $\begin{array}{c}\text { ERK } 1 / 2, \text { JNK and } \\
\text { Bax }\end{array}$ & & [205] \\
\hline Bicalutamide & ZIP9 & antagonist & $\begin{array}{l}\text { 93RS2 (non } \\
\text {-cancerous testicular } \\
\text { cell line) }\end{array}$ & $\begin{array}{l}\text { ERK1/2, CREB and } \\
\text { ATF-1 }\end{array}$ & $\begin{array}{l}\text { Reduced claudin- } 5 \text { and zonula } \\
\text { occludens-1 (ZO-1) expression }\end{array}$ & [206] \\
\hline Nandrolone & OXER1 & antagonist & $\begin{array}{c}\text { MCF-7, } \\
\text { MDA-MB-231 (BC) }\end{array}$ & $\begin{array}{l}\mathrm{PI} 3 \mathrm{~K} / \mathrm{Akt} / \mathrm{NF}-\mathrm{kB} \\
\text { and RACK1 }\end{array}$ & Reduced proliferation and migration & {$[35]$} \\
\hline 5-oxo-EPE & OXER1 & agonist & In vitro assay & & Increased $\beta$-Arrestin recruitment & [207] \\
\hline S-230 & OXER1 & antagonist & $\begin{array}{l}\text { In vivo (monkeys), } \\
\text { human neutrophils }\end{array}$ & $\begin{array}{l}\mathrm{G} \beta \gamma \text {-mediated } \\
\text { signaling }\end{array}$ & $\begin{array}{c}\text { Reduced } \mathrm{G} \beta \gamma \text {-mediated } \mathrm{Ca}^{2+} \\
\text { mobilization }\end{array}$ & {$[208,209]$} \\
\hline S-Y048 & OXER1 & antagonist & $\begin{array}{l}\text { In vivo (monkeys), } \\
\text { human neutrophils } \\
\text { and human } \\
\text { eosinophils }\end{array}$ & $\begin{array}{l}\mathrm{G} \beta \gamma \text {-mediated } \\
\text { signaling }\end{array}$ & $\begin{array}{l}\text { Reduced } \mathrm{G} \beta \gamma \text {-mediated } \mathrm{Ca}^{2+} \\
\text { mobilization, actin polymerization and } \\
\text { eosinophil infiltration }\end{array}$ & [210] \\
\hline S-C025 & OXER1 & antagonist & $\begin{array}{l}\text { In vivo (monkeys), } \\
\text { human neutrophils }\end{array}$ & $\begin{array}{l}\mathrm{G} \beta \gamma \text {-mediated } \\
\text { signaling }\end{array}$ & $\begin{array}{c}\text { Reduced } \mathrm{G} \beta \gamma \text {-mediated } \mathrm{Ca}^{2+} \\
\text { mobilization and eosinophil activation }\end{array}$ & [211] \\
\hline 264 & OXER1 & antagonist & $\begin{array}{l}\text { In vivo (monkeys, } \\
\text { rats), monkey } \\
\text { eosinophils and } \\
\text { monkey neutrophils }\end{array}$ & $\begin{array}{l}\mathrm{G} \beta \gamma \text {-mediated } \\
\text { signaling }\end{array}$ & $\begin{array}{l}\text { Reduced } \mathrm{G} \beta \gamma \text {-mediated } \mathrm{Ca}^{2+} \\
\text { mobilization, actin polymerization and } \\
\text { chemotaxis in granulocytes }\end{array}$ & [212] \\
\hline DJ-V-159 & GPRC6A & agonist & $\begin{array}{l}\text { HEK-293 (human } \\
\text { embryonic kidney), } \\
\text { MIN-6 (mouse } \\
\text { pancreatic } \beta \text {-cell) } \\
\text { and in vivo (mice) }\end{array}$ & $\begin{array}{l}\text { Gos-dependent } \\
\text { signaling, ERK1/2 }\end{array}$ & $\begin{array}{l}\text { Increased cAMP levels, insulin } \\
\text { secretion and decreased serum glucose } \\
\text { (in vivo, mouse) }\end{array}$ & [213] \\
\hline Diltiazem & $\mathrm{CaV} 1.2$ & antagonist & In vivo (mice) & CaV1.2-PKC & Inhibition of $\mathrm{Ca}^{2+}$ influx, PLC $\delta 1$ & [214] \\
\hline Lercanidipine & $\mathrm{CaV} 1.2$ & antagonist & $\begin{array}{c}\text { Healthy and } \\
\text { pediatric acute } \\
\text { myeloid leukemia } \\
\text { (AML) } \\
\text { mesenchymal } \\
\text { stromal cells (MSCs) }\end{array}$ & & Inhibition of $\mathrm{Ca}^{2+}$ influx & [215] \\
\hline Ketamine & $\mathrm{CaV} 1.2$ & antagonist & $\begin{array}{l}\text { In vivo (mice), } \\
\text { Xenopus laevis } \\
\text { oocytes (ex vivo) }\end{array}$ & & $\begin{array}{c}\text { Inhibition of CaV1.2 expression; } \mathrm{Ca}^{2+} \\
\text { influx; and vascular smooth muscle } \\
\text { contraction }\end{array}$ & [216] \\
\hline Ritanserin & $\mathrm{CaV} 1.2$ & antagonist & $\begin{array}{l}\text { Rat vascular } \\
\text { myocytes (ex vivo) }\end{array}$ & & $\begin{array}{c}\text { Inhibition of } \mathrm{Ca}^{2+} \text { influx; in vitro } \\
\text { vasodilation; and vascular smooth } \\
\text { muscle relaxation }\end{array}$ & [217] \\
\hline (R)-Roscovitine & $\mathrm{CaV} 1.2$ & antagonist & HEK-293 & & $\begin{array}{l}\text { Slows activation and enhances } \\
\text { inactivation }\end{array}$ & [218] \\
\hline Metergoline & $\mathrm{NaV} 1.2$ & antagonist & $\begin{array}{c}\text { Xenopus laevis } \\
\text { oocytes (ex vivo) }\end{array}$ & & Inhibition of $\mathrm{Na}^{+}$influx & [219] \\
\hline Ranolazine & $\mathrm{NaV} 1.2$ & antagonist & $\mathrm{CHO}$ & & Inhibition of $\mathrm{Na}^{+}$influx & [220] \\
\hline $\begin{array}{c}2,4(5)- \\
\text { diarylimidazoles }\end{array}$ & $\mathrm{NaV} 1.2$ & antagonist & In vitro assay & & Inhibition of $\mathrm{Na}^{+}$influx & [221] \\
\hline Org OD 02-0 & $\mathrm{mPR} \alpha$ & agonist & $\begin{array}{l}\text { A549, PC-9 (human } \\
\text { lung } \\
\text { adenocarcinoma), } \\
\text { HBE (human } \\
\text { bronchial epithelial) } \\
\text { and MCF-7 }\end{array}$ & $\begin{array}{l}\text { PKA /CREB and } \\
\text { PKA / } \beta \text {-catenin }\end{array}$ & $\begin{array}{l}\text { Inhibition of cell growth and tumor } \\
\text { growth (in vivo) }\end{array}$ & [222] \\
\hline Ganaxolone & $\mathrm{mPR} \delta$ & agonist & $\begin{array}{c}\text { GT1-7 (rat } \\
\text { hypothalamic cells), } \\
\text { H19-7 (rat } \\
\text { hippocampal } \\
\text { neuronal cells) }\end{array}$ & $\begin{array}{l}\text { Gos-dependent } \\
\text { signaling }\end{array}$ & Reduction of apoptosis and cell death & [223] \\
\hline \multirow[t]{3}{*}{ AG-205 } & PGRMC1 & antagonist & $\begin{array}{l}\text { CHO-K1, HeLa, } \\
\text { COS-7, and H4 } \\
\text { glioma Cells }\end{array}$ & & Increased endosome formation & [224] \\
\hline & & & $\begin{array}{c}\text { PaCa- } 2 \text { cells } \\
\text { (pancreatic cancer) }\end{array}$ & $\begin{array}{l}\text { RACK1, } \\
\text { alpha-Actinin-1 }\end{array}$ & $\begin{array}{l}\text { Reduced PGRMC1 interactions with } \\
\text { the actin cytoskeleton }\end{array}$ & [225] \\
\hline & & & $\begin{array}{c}\text { Human } \\
\text { granulosa/luteal } \\
\text { cell }\end{array}$ & $\begin{array}{l}\text { B-cell lymphoma } 2 \\
\text { (BCL2) pathway }\end{array}$ & $\begin{array}{l}\text { Increased PGRMC1 monomeric form, } \\
\text { increased proapoptotic Harakiri (Hrk) } \\
\text { expression }\end{array}$ & [226] \\
\hline
\end{tabular}


Due to the relative novelty of mSRs as mediators of steroid signaling, studies on mSRactive compounds here presented were limited to the pre-clinical phase. Regarding ZIP9, both an antagonist and agonist compounds were analyzed for their ability to modulate ERK1/2, JNK and Bax pathways in both prostate and breast cancer cell lines with a final effect on apoptosis regulation. For OXER1, different antagonists were synthetized and screened both in vitro and in vivo, mostly for their ability to reduce inflammation-related pathways. In addition, several natural compounds were examined for their binding affinity for ZIP9, OXER1 and GPRC6A, although this analysis was limited to in silico data [227]. For $\mathrm{mPR} \alpha$ and PGRMC1, an agonist and antagonist compounds have been reported, respectively. On the other hand, for CaV1.2, only antagonist compounds were described, even though cardiotoxicity or neurotoxocity were reported upon its blockade $[228,229]$. Finally, for GPRC6A, only an agonist has been reported, although an antagonist profile for its targeting could be more useful considering its inflammatory role regarding cytokine release [230]. Considering different and opposite tumor-dependent effects of the different mSRs, it will be important to develop targeted delivery systems to limit unwanted off-target effects.

\section{Conclusions}

Hormone-mediated rapid non-genomic effects, which cannot be attributed to the genomic action of nSRs, have raised attention on the potential involvement of mSRs in modulating specific molecular pathways pivotal for the physiologic hormone action. More recently, a possible contribution of mSRs to the development of hormone-linked diseases has been hypothesized, including hormone-related cancers. Because of their widespread expression in different human tissues, their role in promoting and driving not only the cancerous process itself but also other cancer-sustaining mechanisms in the surrounding TME Therefore, their ability to bind and exert the action of hormones and hormone-like substances (e.g., EDCs), also in a pathologic context, indicated, on one hand, their potential involvement in shaping the TME characteristic to support the tumor growth and, on the other, offered new insights into their potential as therapeutic targets. However, the limited knowledge on mSRs also as EDCs targets warrants further studies to dissect and elucidate their role in mediating non-physiologic mechanisms of endocrine disruption that can have an important impact on the development and progression of different hormone-linked diseases with a strong or hypothesized environmental component, including hormonesensitive cancers. Moreover, the early-stage translational research on mSRs as novel drug targets requires additional studies for the development of new small molecules capable to specifically target these receptors and hinder or amplify their correlated action to counteract cancer development.

Author Contributions: Conceptualization, M.M., E.C. and E.B. writing-original draft, M.M. and E.B. writing—review and editing, M.M., M.R., C.T., E.C. and E.B. visualization, M.M., M.R., C.T., E.C. and E.B. critical discussion, M.M., M.R., C.T., E.C. and E.B. All authors have read and agreed to the published version of the manuscript.

Funding: Research has been supported by Ministero dell'Istruzione, dell'Università e della Ricerca to Emanuela Corsini (PRIN2017, Project number 2017MLC3NF) and to Marco Racchi (PRIN2017, Project number 2017B9NCSX).

Acknowledgments: The authors would like to thank SMART-Servier Medical ART (https:/ /smart. servier.com/, accessed on 14 September 2021) used for performing Figures 1-4.

Conflicts of Interest: The authors declare no conflict of interests.

\section{References}

1. Ferlay, J.; Colombet, M.; Soerjomataram, I.; Parkin, D.M.; Piñeros, M.; Znaor, A.; Bray, F. Cancer statistics for the year 2020: An overview. Int. J. Cancer 2021, 149, 778-789. [CrossRef] [PubMed]

2. Henderson, B.E.; Feigelson, H.S. Hormonal carcinogenesis. Carcinogenesis 2000, 21, 427-433. [CrossRef] 
3. Buoso, E.; Masi, M.; Racchi, M.; Corsini, E. Endocrine-Disrupting Chemicals' (EDCs) Effects on Tumour Microenvironment and Cancer Progression: Emerging Contribution of RACK1. Int. J. Mol. Sci. 2020, 21, 9229. [CrossRef] [PubMed]

4. Kravchenko, J.; Corsini, E.; Williams, M.A.; Decker, W.; Manjili, M.H.; Otsuki, T.; Singh, N.; Al-Mulla, F.; Altemaimi, R.; Amedei, A.; et al. Chemical compounds from anthropogenic environment and immune evasion mechanisms: Potential interactions. Carcinogenesis 2015, 36, S111-S127. [CrossRef]

5. Whirledge, S.; Cidlowski, J.A. Chapter 5-Steroid Hormone Action. In Yen and Jaffe's Reproductive Endocrinology: Physiology, Pathophysiology, and Clinical Management, 8th ed.; Strauss, J., Barbieri, R., Eds.; Elsevier: Amsterdam, The Netherlands, 2018; pp. 115-131.

6. Levin, E.R. Translating extranuclear steroid receptor signaling to clinical medicine. Horm. Cancer 2014, 5, 140-145. [CrossRef]

7. Hammes, S.R.; Levin, E.R. Minireview: Recent advances in extranuclear steroid receptor actions. Endocrinology 2011, 152, 4489-4495. [CrossRef] [PubMed]

8. Pedram, A.; Razandi, M.; Sainson, R.C.; Kim, J.K.; Hughes, C.C.; Levin, E.R. A Conserved Mechanism for Steroid Receptor Translocation to the Plasma Membrane. J. Biol. Chem. 2007, 282, 22278-22288. [CrossRef]

9. Thomas, P. Membrane Androgen Receptors Unrelated to Nuclear Steroid Receptors. Endocrinology 2019, 160, 772-781. [CrossRef] [PubMed]

10. Treviño, L.S.; Gorelick, D.A. The Interface of Nuclear and Membrane Steroid Signaling. Endocrinology 2021, 162, bqab107. [CrossRef] [PubMed]

11. Lichten, L.A.; Cousins, R.J. Mammalian Zinc Transporters: Nutritional and Physiologic Regulation. Annu. Rev. Nutr. 2009, 29, 153-176. [CrossRef]

12. Thomas, P.; Converse, A.; Berg, H. ZIP9, a novel membrane androgen receptor and zinc transporter protein. Gen. Comp. Endocrinol. 2018, 257, 130-136. [CrossRef]

13. Thomas, P.; Pang, Y.; Dong, J. Membrane androgen receptor characteristics of human ZIP9 (SLC39A) zinc transporter in prostate cancer cells: Androgen-specific activation and involvement of an inhibitory G protein in zinc and MAP kinase signaling. Mol. Cell. Endocrinol. 2017, 447, 23-34. [CrossRef] [PubMed]

14. Taniguchi, M.; Fukunaka, A.; Hagihara, M.; Watanabe, K.; Kamino, S.; Kambe, T.; Enomoto, S.; Hiromura, M. Essential Role of the Zinc Transporter ZIP9/SLC39A9 in Regulating the Activations of Akt and Erk in B-Cell Receptor Signaling Pathway in DT40 Cells. PLoS ONE 2013, 8, e58022. [CrossRef] [PubMed]

15. Thomas, P.; Pang, Y.; Dong, J.; Berg, H. Identification and Characterization of Membrane Androgen Receptors in the ZIP9 Zinc Transporter Subfamily: II. Role of Human ZIP9 in Testosterone-Induced Prostate and Breast Cancer Cell Apoptosis. Endocrinology 2014, 155, 4250-4265. [CrossRef] [PubMed]

16. Pascal, L.; Wang, Z. Unzipping Androgen Action Through ZIP9: A Novel Membrane Androgen Receptor. Endocrinology 2014, 155, 4120-4123. [CrossRef]

17. Bulldan, A.; Bartsch, J.W.; Konrad, L.; Scheiner-Bobis, G. ZIP9 but not the androgen receptor mediates testosterone-induced migratory activity of metastatic prostate cancer cells. Biochim. Biophys. Acta Bioenerg. 2018, 1865, 1857-1868. [CrossRef]

18. Kalyvianaki, K.; Panagiotopoulos, A.A.; Malamos, P.; Moustou, E.; Tzardi, M.; Stathopoulos, E.N.; Ioannidis, G.S.; Marias, K.; Notas, G.; Theodoropoulos, P.A.; et al. Membrane androgen receptors (OXER1, GPRC6A AND ZIP9) in prostate and breast cancer: A comparative study of their expression. Steroids 2019, 142, 100-108. [CrossRef]

19. Liu, L.; Yang, J.; Wang, C. Analysis of the prognostic significance of solute carrier (SLC) family 39 genes in breast cancer. Biosci. Rep. 2020, 40, BSR20200764. [CrossRef]

20. Kim, J.; Kim, S.; Ko, S.; In, Y.-H.; Moon, H.-G.; Ahn, S.K.; Kim, M.K.; Lee, M.; Hwang, J.-H.; Ju, Y.S.; et al. Recurrent fusion transcripts detected by whole-transcriptome sequencing of 120 primary breast cancer samples. Genes Chromosom. Cancer 2015, 54, 681-691. [CrossRef]

21. Hosoi, T.; Koguchi, Y.; Sugikawa, E.; Chikada, A.; Ogawa, K.; Tsuda, N.; Suto, N.; Tsunoda, S.; Taniguchi, T.; Ohnuki, T. Identification of a Novel Human Eicosanoid Receptor Coupled to Gi/o. J. Biol. Chem. 2002, 277, 31459-31465. [CrossRef] [PubMed]

22. Grant, G.E.; Rokach, J.; Powell, W.S. 5-Oxo-ETE and the OXE receptor. Prostaglandins Lipid Mediat. 2009, 89, 98-104. [CrossRef]

23. Sarveswaran, S.; Ghosh, J. OXER1, a G protein-coupled oxoeicosatetraenoid receptor, mediates the survival-promoting effects of arachidonate 5-lipoxygenase in prostate cancer cells. Cancer Lett. 2013, 336, 185-195. [CrossRef] [PubMed]

24. Konya, V.; Blättermann, S.; Jandl, K.; Platzer, W.; Ottersbach, P.A.; Marsche, G.; Gütschow, M.; Kostenis, E.; Heinemann, A. A

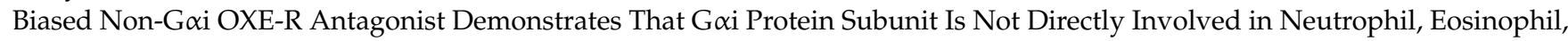
and Monocyte Activation by 5-Oxo-ETE. J. Immunol. 2014, 192, 4774-4782. [CrossRef]

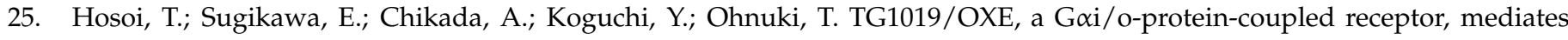
5-oxo-eicosatetraenoic acid-induced chemotaxis. Biochem. Biophys. Res. Commun. 2005, 334, 987-995. [CrossRef]

26. Sarveswaran, S.; Thamilselvan, V.; Brodie, C.; Ghosh, J. Inhibition of 5-lipoxygenase triggers apoptosis in prostate cancer cells via down-regulation of protein kinase C-epsilon. Biochim. Biophys. Acta Bioenerg. 2011, 1813, 2108-2117. [CrossRef]

27. Langlois, A.; Chouinard, F.; Flamand, N.; Ferland, C.; Rola-Pleszczynski, M.; Laviolette, M. Crucial implication of protein kinase C (PKC)-, PKC-, ERK-1/2, and p38 MAPK in migration of human asthmatic eosinophils. J. Leukoc. Biol. 2009, 85, 656-663. [CrossRef] [PubMed] 
28. O'Flaherty, J.T.; Rogers, L.C.; Paumi, C.M.; Hantgan, R.R.; Thomas, L.R.; Clay, C.E.; High, K.; Chen, Y.Q.; Willingham, M.C.; Smitherman, P.K.; et al. 5-Oxo-ETE analogs and the proliferation of cancer cells. Biochim. Biophys. Acta Mol. Cell Biol. Lipids 2005, 1736, 228-236. [CrossRef] [PubMed]

29. Sundaram, S.; Ghosh, J. Expression of 5-oxoETE receptor in prostate cancer cells: Critical role in survival. Biochem. Biophys. Res. Commun. 2006, 339, 93-98. [CrossRef]

30. Grant, G.E.; Rubino, S.; Gravel, S.; Wang, X.; Patel, P.; Rokach, J.; Powell, W.S. Enhanced formation of 5-oxo-6,8,11,14eicosatetraenoic acid by cancer cells in response to oxidative stress, docosahexaenoic acid and neutrophil-derived 5-hydroxy6,8,11,14-eicosatetraenoic acid. Carcinogenesis 2011, 32, 822-828. [CrossRef]

31. Kalyvianaki, K.; Gebhart, V.; Peroulis, N.; Panagiotopoulou, C.; Kiagiadaki, F.; Pediaditakis, I.; Aivaliotis, M.; Moustou, E.; Tzardi, M.; Notas, G.; et al. Antagonizing effects of membrane-acting androgens on the eicosanoid receptor OXER1 in prostate cancer. Sci. Rep. 2017, 7, srep44418. [CrossRef]

32. Kampa, M.; Notas, G.; Castanas, E. Natural extranuclear androgen receptor ligands as endocrine disruptors of cancer cell growth. Mol. Cell. Endocrinol. 2017, 457, 43-48. [CrossRef] [PubMed]

33. Notas, G.; Pelekanou, V.; Castanas, E.; Kampa, M. Conjugated and non-conjugated androgens differentially modulate specific early gene transcription in breast cancer in a cell-specific manner. Steroids 2010, 75, 611-618. [CrossRef] [PubMed]

34. Kampa, M.; Nifli, A.-P.; Charalampopoulos, I.; Alexaki, V.-I.; Theodoropoulos, P.A.; Stathopoulos, E.N.; Gravanis, A.; Castanas, E. Opposing effects of estradiol- and testosterone-membrane binding sites on T47D breast cancer cell apoptosis. Exp. Cell Res. 2005, 307, 41-51. [CrossRef]

35. Masi, M.; Garattini, E.; Bolis, M.; Di Marino, D.; Maraccani, L.; Morelli, E.; Grolla, A.A.; Fagiani, F.; Corsini, E.; Travelli, C.; et al. OXER1 and RACK1-associated pathway: A promising drug target for breast cancer progression. Onco-Genesis 2020, 9, 1-15. [CrossRef]

36. Singh, A.K.; Singh, R.; Naz, F.; Chauhan, S.S.; Dinda, A.; Shukla, A.A.; Gill, K.; Kapoor, V.; Dey, S. Structure Based Design and Synthesis of Peptide Inhibitor of Human LOX-12: In Vitro and In Vivo Analysis of a Novel Therapeutic Agent for Breast Cancer. PLoS ONE 2012, 7, e32521. [CrossRef]

37. Kumar, R.; Singh, A.K.; Kumar, M.; Shekhar, S.; Rai, N.; Kaur, P.; Parshad, R.; Dey, S. Serum 5-LOX: A progressive protein marker for breast cancer and new approach for therapeutic target. Carcinogenesis 2016, 37, 912-917. [CrossRef] [PubMed]

38. R2: Genomics Analysis and Visualization Platform. Available online: http://r2.amc.nl (accessed on 12 July 2021).

39. Yi, S.; Zhou, W. Tumorigenesis-related key genes in adolescents and young adults with HR(+)/HER2(-) breast cancer. Int. J. Clin. Exp. Pathol. 2020, 13, 2701-2709.

40. Pi, M.; Nishimoto, S.K.; Quarles, L.D. GPRC6A: Jack of all metabolism (or master of none). Mol. Metab. 2017, 6, 185-193. [CrossRef] [PubMed]

41. Ye, R.; Pi, M.; Cox, J.V.; Nishimoto, S.K.; Quarles, L.D. CRISPR/Cas9 targeting of GPRC6A suppresses prostate cancer tumorigenesis in a human xenograft model. J. Exp. Clin. Cancer Res. 2017, 36, 1-13. [CrossRef]

42. Ye, R.; Pi, M.; Nooh, M.M.; Bahout, S.W.; Quarles, L.D. Human GPRC6A Mediates Testosterone-Induced Mitogen-Activated Protein Kinases and mTORC1 Signaling in Prostate Cancer Cells. Mol. Pharmacol. 2019, 95, 563-572. [CrossRef]

43. Takata, R.; Akamatsu, S.; Kubo, M.; Takahashi, A.; Hosono, N.; Kawaguchi, T.; Tsunoda, T.; Inazawa, J.; Kamatani, N.; Ogawa, O.; et al. Genome-wide association study identifies five new susceptibility loci for prostate cancer in the Japanese population. Nat. Genet. 2010, 42, 751-754. [CrossRef]

44. Long, Q.-Z.; Du, Y.-F.; Ding, X.-Y.; Li, X.; Song, W.-B.; Yang, Y.; Zhang, P.; Zhou, J.-P.; Liu, X.-G. Replication and Fine Mapping for Association of the C2orf43, FOXP4, GPRC6A and RFX6 Genes with Prostate Cancer in the Chinese Population. PLoS ONE 2012, 7, e37866. [CrossRef] [PubMed]

45. Li, X.-H.; Xu, Y.; Yang, K.; Shi, J.-J.; Zhang, X.; Yang, F.; Yuan, H.; Zhu, X.; Zhang, Y.-H.; Wang, J.-Y.; et al. Association of THADA, FOXP4, GPRC6A/RFX6 genes and 8q24 risk alleles with prostate cancer in Northern Chinese men. Off. J. Balk. Union Oncol. 2015, $20,1223-1228$.

46. Qi, N.; Chen, Y.; Zeng, Y.; Bao, M.; Long, X.; Guo, Y.; Tan, A.; Gao, Y.; Zhang, H.; Yang, X.; et al. rs2274911 polymorphism in GPRC6A associated with serum E2 and PSA in a Southern Chinese male population. Gene 2020, 763, 145067. [CrossRef] [PubMed]

47. Liu, M.; Zhao, Y.-Y.; Yang, F.; Wang, J.-Y.; Shi, X.-H.; Zhu, X.-Q.; Xu, Y.; Wei, D.; Sun, L.; Zhang, Y.-G.; et al. Evidence for a role of GPRC6A in prostate cancer metastasis based on case-control and in vitro analyses. Eur. Rev. Med. Pharmacol. Sci. 2016, 20, 2235-2248.

48. Asuthkar, S.; Elustondo, P.A.; Demirkhanyan, L.; Sun, X.; Baskaran, P.; Velpula, K.K.; Thyagarajan, B.; Pavlov, E.V.; Zakharian, E. The TRPM8 Protein Is a Testosterone Receptor. J. Biol. Chem. 2015, 290, 2659-2669. [CrossRef] [PubMed]

49. Asuthkar, S.; Demirkhanyan, L.; Sun, X.; Elustondo, P.A.; Krishnan, V.; Baskaran, P.; Velpula, K.K.; Thyagarajan, B.; Pavlov, E.V.; Zakharian, E. The TRPM8 Protein Is a Testosterone Receptor. J. Biol. Chem. 2015, 290, 2670-2688. [CrossRef]

50. Wang, Y.; Wang, X.; Yang, Z.; Zhu, G.; Chen, D.; Meng, Z. Menthol Inhibits the Proliferation and Motility of Prostate Cancer DU145 Cells. Pathol. Oncol. Res. 2012, 18, 903-910. [CrossRef]

51. Liu, Y.; Mikrani, R.; He, Y.; Baig, M.M.F.A.; Abbas, M.; Naveed, M.; Tang, M.; Zhang, Q.; Li, C.; Zhou, X. TRPM8 channels: A review of distribution and clinical role. Eur. J. Pharmacol. 2020, 882, 173312. [CrossRef]

52. Cunha, A.; Weigle, B.; Kiessling, A.; Bachmann, M.; Rieber, E.P. Tissue-specificity of prostate specific antigens: Comparative analysis of transcript levels in prostate and non-prostatic tissues. Cancer Lett. 2006, 236, 229-238. [CrossRef] 
53. Lunardi, A.; Barbareschi, M.; Carbone, F.G.; Morelli, L.; Brunelli, M.; Fortuna, N.; Genovesi, S.; Alaimo, A. TRPM8 protein expression in hormone naïve local and lymph node metastatic prostate cancer. Pathologica 2021, 113, 95-101. [CrossRef]

54. Henshall, S.M.; Afar, D.E.; Hiller, J.; Horvath, L.G.; Quinn, D.I.; Rasiah, K.K.; Gish, K.; Willhite, D.; Kench, J.G.; Gardiner-Garden, M.; et al. Survival analysis of genome-wide gene expression pro-files of prostate cancers identifies new prognostic targets of disease relapse. Cancer Res. 2003, 63, 4196-4203.

55. Alaimo, A.; De Felice, D.; Genovesi, S.; Lorenzoni, M.; Lunardi, A. Tune the channel: TRPM8 targeting in prostate cancer. Oncoscience 2021, 8, 97-100. [CrossRef]

56. Zhang, X.S.; Zhang, Y.; Wu, P.X.; Liu, S.J.; Zhou, J.Y.; Liu, S.X. Early diagnosis of prostate cancer by combined use of Trp-p8 expres-sion and PSA density of the transition zone. Zhonghua Nan Ke Xue 2015, 21, 724-728.

57. Lunger, L.; Retz, M.; Bandur, M.; Souchay, M.; Vitzthum, E.; Jäger, M.; Weirich, G.; Schuster, T.; Autenrieth, M.; Kübler, H.; et al. KLK3 and TMPRSS2 for molecular lymph-node staging in prostate cancer patients undergoing radical prostatectomy. Prostate Cancer Prostatic Dis. 2021, 24, 362-369. [CrossRef] [PubMed]

58. Bai, V.U.; Murthy, S.; Chinnakannu, K.; Muhletaler, F.; Tejwani, S.; Barrack, E.R.; Kim, S.H.; Menon, M.; Veer Reddy, G.P. Androgen regulated TRPM8 expression: A potential mRNA marker for metastatic prostate cancer detection in body fluids. Int. J. Oncol. 2010, 36, 443-450.

59. Huskova, Z.; Knillova, J.; Kolar, Z.; Vrbkova, J.; Kral, M.; Bouchal, J. The Percentage of Free PSA and Urinary Markers Distinguish Prostate Cancer from Benign Hyperplasia and Contribute to a More Accurate Indication for Prostate Biopsy. Biomedicines 2020, 8, 173. [CrossRef] [PubMed]

60. Dhennin-Duthille, I.; Gautier, M.; Faouzi, M.; Guilbert, A.; Brevet, M.; Vaudry, D.; Ahidouch, A.; Sevestre, H.; Ouadid-Ahidouch, H. High Expression of Transient Receptor Potential Channels in Human Breast Cancer Epithelial Cells and Tissues: Correlation with Pathological Parameters. Cell. Physiol. Biochem. 2011, 28, 813-822. [CrossRef]

61. Liu, J.; Chen, Y.; Shuai, S.; Ding, D.; Li, R.; Luo, R. TRPM8 promotes aggressiveness of breast cancer cells by regulating EMT via activating AKT/GSK-3ß pathway. Tumor Biol. 2014, 35, 8969-8977. [CrossRef] [PubMed]

62. Huang, Y.; Li, S.; Jia, Z.; Zhao, W.; Zhou, C.; Zhang, R.; Ali, D.W.; Michalak, M.; Chen, X.-Z.; Tang, J. Transient Receptor Potential Melastatin 8 (TRPM8) Channel Regulates Proliferation and Migration of Breast Cancer Cells by Activating the AMPK-ULK1 Pathway to Enhance Basal Autophagy. Front. Oncol. 2020, 10, 2645. [CrossRef] [PubMed]

63. Ouadid-Ahidouch, H.; Dhennin-Duthille, I.; Gautier, M.; Sevestre, H.; Ahidouch, A. Canaux cationiques TRP dans le cancer du sein: Expression, rôle et corrélation avec des paramètres cliniques. Bull. Cancer 2012, 99, 655-664. [CrossRef]

64. Pratt, S.J.P.; Lee, R.M.; Chang, K.T.; Hernández-Ochoa, E.O.; Annis, D.A.; Ory, E.C.; Thompson, K.N.; Bailey, P.C.; Mathias, T.J.; Ju, J.A.; et al. Mechanoactivation of NOX2-generated ROS elicits persistent TRPM8 $\mathrm{Ca}^{2+}$ signals that are inhibited by oncogenic KRas. Proc. Natl. Acad. Sci. USA 2020, 117, 26008-26019. [CrossRef]

65. Zamponi, G.; Striessnig, J.; Koschak, A.; Dolphin, A.C. The Physiology, Pathology, and Pharmacology of Voltage-Gated Calcium Channels and Their Future Therapeutic Potential. Pharmacol. Rev. 2015, 67, 821-870. [CrossRef] [PubMed]

66. Murphy, J.G.; Sanderson, J.L.; Gorski, J.A.; Scott, J.D.; Catterall, W.A.; Sather, W.A.; Dell'Acqua, M.L. AKAP-Anchored PKA Maintains Neuronal L-type Calcium Channel Activity and NFAT Transcriptional Signaling. Cell Rep. 2014, 7, 1577-1588. [CrossRef]

67. Qin, J.; Nag, S.; Wang, W.; Zhou, J.; Zhang, W.-D.; Wang, H.; Zhang, R. NFAT as cancer target: Mission possible? Biochim. Biophys. Acta Bioenerg. 2014, 1846, 297-311. [CrossRef]

68. Mancini, M.; Toker, A. NFAT proteins: Emerging roles in cancer progression. Nat. Rev. Cancer 2009, 9, 810-820. [CrossRef]

69. Déliot, N.; Constantin, B. Plasma membrane calcium channels in cancer: Alterations and consequences for cell proliferation and migration. Biochim. Biophys. Acta Biomembr. 2015, 1848, 2512-2522. [CrossRef] [PubMed]

70. Marques, R.; Peres, C.G.; Vaz, C.V.; Gomes, I.M.; Figueira, M.I.; Cairrão, E.; Verde, I.; Maia, C.J.; Socorro, S. $5 \alpha$-Dihydrotestosterone regulates the expression of L-type calcium channels and calcium-binding protein regucalcin in human breast cancer cells with suppression of cell growth. Med. Oncol. 2015, 32, 228. [CrossRef] [PubMed]

71. Scragg, J.L.; Dallas, M.L.; Peers, C. Molecular requirements for L-type $\mathrm{Ca}^{2+}$ channel blockade by testosterone. Cell Calcium 2007, 42, 11-15. [CrossRef]

72. Soltysik, K.; Czekaj, P. Membrane estrogen receptors-Is it an alternative way of estrogen action? J. Physiol. Pharmacol. 2013, 64, 129-142.

73. Taheri, M.; Shoorei, H.; Dinger, M.E.; Ghafouri-Fard, S. Perspectives on the Role of Non-Coding RNAs in the Regulation of Expression and Function of the Estrogen Receptor. Cancers 2020, 12, 2162. [CrossRef]

74. Kampa, M.; Notas, G.; Pelekanou, V.; Troullinaki, M.; Andrianaki, M.; Azariadis, K.; Kampouri, E.; Lavrentaki, K.; Castanas, E. Early membrane initiated transcriptional effects of estrogens in breast cancer cells: First pharmacological evidence for a novel membrane estrogen receptor element (ERx). Steroids 2012, 77, 959-967. [CrossRef]

75. Elappano, R.; Episano, A.; Maggiolini, M. GPER Function in Breast Cancer: An Overview. Front. Endocrinol. 2014, 5, 66. [CrossRef]

76. Marjon, N.A.; Hu, C.; Hathaway, H.J.; Prossnitz, E.R. G Protein-Coupled Estrogen Receptor Regulates Mammary Tumorigenesis and Metastasis. Mol. Cancer Res. 2014, 12, 1644-1654. [CrossRef]

77. Prossnitz, E.R.; Arterburn, J.B. International Union of Basic and Clinical Pharmacology. XCVII. G Protein-Coupled Estrogen Receptor and Its Pharmacologic Modulators. Pharmacol. Rev. 2015, 67, 505-540. [CrossRef] 
78. Prossnitz, E.R.; Arterburn, J.B.; Smith, H.O.; Oprea, T.I.; Sklar, L.A.; Hathaway, H.J. Estrogen Signaling through the Transmembrane G Protein-Coupled Receptor GPR30. Annu. Rev. Physiol. 2008, 70, 165-190. [CrossRef]

79. Thomas, P.; Pang, Y.; Filardo, E.; Dong, J. Identity of an Estrogen Membrane Receptor Coupled to a G Protein in Human Breast Cancer Cells. Endocrinology 2005, 146, 624-632. [CrossRef]

80. Revankar, C.M.; Cimino, D.F.; Sklar, L.A.; Arterburn, J.B.; Prossnitz, E.R. A Transmembrane Intracellular Estrogen Receptor Mediates Rapid Cell Signaling. Science 2005, 307, 1625-1630. [CrossRef]

81. Hugo, E.R.; Brandebourg, T.D.; Woo, J.G.; Loftus, J.; Alexander, J.W.; Ben-Jonathan, N. Bisphenol A at Environmentally Relevant Doses Inhibits Adiponectin Release from Human Adipose Tissue Explants and Adipocytes. Environ. Health Perspect. 2008, 116, 1642-1647. [CrossRef]

82. Shi, H.; Kumar, S.P.D.S.; Liu, X. G Protein-Coupled Estrogen Receptor in Energy Homeostasis and Obesity Pathogenesis. Prog. Mol. Biol. Transl. Sci. 2013, 114, 193-250. [CrossRef]

83. Luo, J.; Liu, D. Does GPER Really Function as a G Protein-Coupled Estrogen Receptor in vivo? Front. Endocrinol. 2020, 11, 148. [CrossRef]

84. Prossnitz, E.R.; Hathaway, H.J. What have we learned about GPER function in physiology and disease from knockout mice? J. Steroid Biochem. Mol. Biol. 2015, 153, 114-126. [CrossRef]

85. Jung, J. Role of G Protein-Coupled Estrogen Receptor in Cancer Progression. Toxicol. Res. 2019, 35, 209-214. [CrossRef]

86. Talia, M.; De Francesco, E.M.; Rigiracciolo, D.C.; Muoio, M.G.; Muglia, L.; Belfiore, A.; Maggiolini, M.; Sims, A.H.; Lappano, R. The G Protein-Coupled Estrogen Receptor (GPER) Expression Correlates with Pro-Metastatic Pathways in ER-Negative Breast Cancer: A Bioinformatics Analysis. Cells 2020, 9, 622. [CrossRef]

87. Zhou, X.; Wang, S.; Wang, Z.; Feng, X.; Liu, P.; Lv, X.-B.; Kun-Liang, G.; Yu, F.-X.; Sun, Y.; Yuan, H.; et al. Estrogen regulates Hippo signaling via GPER in breast cancer. J. Clin. Investig. 2015, 125, 2123-2135. [CrossRef]

88. Wang, Z.; Sun, L.; Liang, S.; Liu, Z.-C.; Zhao, Z.-Y.; Yang, J.; Wang, D.; Yang, D.-Q. GPER stabilizes F-actin cytoskeleton and activates TAZ via PLC $\beta$-PKC and Rho/ROCK-LIMK-Cofilin pathway. Biochem. Biophys. Res. Commun. 2019, 516, 976-982. [CrossRef]

89. Yang, H.; Wang, C.; Liao, H.; Wang, Q. Activation of GPER by E2 promotes proliferation, invasion and migration of breast cancer cells by regulating the miR-124/CD151 pathway. Oncol. Lett. 2021, 21, 1-9. [CrossRef]

90. Tao, S.; He, H.; Chen, Q.; Yue, W. GPER mediated estradiol reduces miR-148a to promote HLA-G expression in breast cancer. Biochem. Biophys. Res. Commun. 2014, 451, 74-78. [CrossRef]

91. Tao, S.; He, H.; Chen, Q. Estradiol induces HOTAIR levels via GPER-mediated miR-148a inhibition in breast cancer. J. Transl. Med. 2015, 13, 1-8. [CrossRef]

92. Magruder, H.T.; Quinn, J.A.; Schwartzbauer, J.E.; Reichner, J.; Huang, A.; Filardo, E.J. The G Protein-Coupled Estrogen Receptor-1, GPER-1, Promotes Fibrillogenesis via a Shc-Dependent Pathway Resulting in Anchorage-Independent Growth. Horm. Cancer 2014, 5, 390-404. [CrossRef]

93. Santolla, M.F.; Avino, S.; Pellegrino, M.A.; De Francesco, E.M.; De Marco, P.; Lappano, R.; Vivacqua, A.; Cirillo, F.; Rigiracciolo, D.C.; Scarpelli, A.; et al. SIRT1 is involved in oncogenic signaling mediated by GPER in breast cancer. Cell Death Dis. 2015, 6, e1834. [CrossRef] [PubMed]

94. Yin, H.; Zhu, Q.; Liu, M.; Tu, G.; Li, Q.; Yuan, J.; Wen, S.; Yang, G. GPER promotes tamoxifen-resistance in ER+ breast cancer cells by reduced Bim proteins through MAPK/Erk-TRIM2 signaling axis. Int. J. Oncol. 2017, 51, 1191-1198. [CrossRef]

95. Zekas, E.; Prossnitz, E.R. Estrogen-mediated inactivation of FOXO3a by the G protein-coupled estrogen receptor GPER. BMC Cancer 2015, 15, 1-12. [CrossRef]

96. Chan, Y.; Lai, A.C.; Lin, R.; Wang, Y.; Wang, Y.; Chang, W.-W.; Wu, H.; Lin, Y.; Wu, J.; Yu, J.; et al. GPER-induced signaling is essential for the survival of breast cancer stem cells. Int. J. Cancer 2020, 146, 1674-1685. [CrossRef]

97. Yu, T.; Cheng, H.; Ding, Z.; Wang, Z.; Zhou, L.; Zhao, P.; Tan, S.; Xu, X.; Huang, X.; Liu, M.; et al. GPER mediates decreased chemosensitivity via regulation of ABCG2 expression and localization in tamoxifen-resistant breast cancer cells. Mol. Cell. Endocrinol. 2020, 506, 110762. [CrossRef]

98. Ignatov, T.; Treeck, O.; Kalinski, T.; Ortmann, O.; Ignatov, A. GPER-1 expression is associated with a decreased response rate to primary tamoxifen therapy of breast cancer patients. Arch. Gynecol. Obstet. 2020, 301, 565-571. [CrossRef]

99. Molina, L.; Bustamante, F.; Ortloff, A.; Ramos, I.; Ehrenfeld, P.; Figueroa, C.D. Continuous Exposure of Breast Cancer Cells to Tamoxifen Upregulates GPER-1 and Increases Cell Proliferation. Front. Endocrinol. 2020, 11, 563165. [CrossRef] [PubMed]

100. Weißenborn, C.; Ignatov, T.; Poehlmann, A.; Wege, A.K.; Costa, S.D.; Zenclussen, A.; Ignatov, A. GPER functions as a tumor suppressor in MCF-7 and SK-BR-3 breast cancer cells. J. Cancer Res. Clin. Oncol. 2014, 140, 663-671. [CrossRef]

101. Martin, S.; Lebot, M.N.; Sukkarn, B.; Ball, G.; Green, A.; Rakha, E.A.; Ellis, I.; Storr, S.J. Low expression of G protein-coupled oestrogen receptor 1 (GPER) is associated with adverse survival of breast cancer patients. Oncotarget 2018, 9, 25946-25956. [CrossRef]

102. Tutzauer, J.; Sjöström, M.; Bendahl, P.-O.; Rydén, L.; Fernö, M.; Leeb-Lundberg, L.M.F.; Alkner, S. Plasma membrane expression of $G$ protein-coupled estrogen receptor (GPER)/G protein-coupled receptor 30 (GPR30) is associated with worse outcome in metachronous contralateral breast cancer. PLoS ONE 2020, 15, e0231786. [CrossRef]

103. Weissenborn, C.; Ignatov, T.; Nass, N.; Kalinski, T.; Costa, S.D.; Zenclussen, A.C.; Ignatov, A. GPER Promoter Methylation Controls GPER Expression in Breast Cancer Patients. Cancer Investig. 2017, 35, 1-8. [CrossRef] 
104. Hernández-Silva, C.D.; Villegas-Pineda, J.C.; Pereira-Suárez, A.L. Expression and Role of the G Protein-Coupled Estrogen Receptor (GPR30/GPER) in the Development and Immune Response in Female Reproductive Cancers. Front. Endocrinol. 2020, 11, 544. [CrossRef]

105. Ignatov, T.; Modl, S.; Thulig, M.; Weißenborn, C.; Treeck, O.; Ortmann, O.; Zenclussen, A.; Costa, S.D.; Kalinski, T.; Ignatov, A. GPER-1 acts as a tumor suppressor in ovarian cancer. J. Ovarian Res. 2013, 6, 51. [CrossRef] [PubMed]

106. Fraungruber, P.; Kaltofen, T.; Heublein, S.; Kuhn, C.; Mayr, D.; Burges, A.; Mahner, S.; Rathert, P.; Jeschke, U.; Trillsch, F. G Protein-Coupled Estrogen Receptor Correlates with Dkk2 Expression and Has Prognostic Impact in Ovarian Cancer Patients. Front. Endocrinol. 2021, 12, 18. [CrossRef]

107. Heublein, S.; Mayr, D.; Vrekoussis, T.; Friese, K.; Hofmann, S.S.; Jeschke, U.; Lenhard, M. The G-Protein Coupled Estrogen Receptor (GPER/GPR30) is a Gonadotropin Receptor Dependent Positive Prognosticator in Ovarian Carcinoma Patients. PLoS ONE 2013, 8, e71791. [CrossRef] [PubMed]

108. Wang, C.; Lv, X.; Jiang, C.; Davis, J.S. The putative G-protein coupled estrogen receptor agonist G-1 suppresses proliferation of ovarian and breast cancer cells in a GPER-independent manner. Am. J. Transl. Res. 2012, 4, 390-402. [PubMed]

109. Wang, C.; Lv, X.; He, C.; Hua, G.; Tsai, M.-Y.; Davis, J.S. The G-protein-coupled estrogen receptor agonist G-1 suppresses proliferation of ovarian cancer cells by blocking tubulin polymerization. Cell Death Dis. 2013, 4, e869. [CrossRef] [PubMed]

110. Schüler-Toprak, S.; Skrzypczak, M.; Ignatov, T.; Ignatov, A.; Ortmann, O.; Treeck, O. G protein-coupled estrogen receptor 1 (GPER-1) and agonist G-1 inhibit growth of ovarian cancer cells by activation of anti-tumoral transcriptome responses: Impact of GPER-1 mRNA on survival. J. Cancer Res. Clin. Oncol. 2020, 146, 3175-3188. [CrossRef]

111. Han, N.; Heublein, S.; Jeschke, U.; Kuhn, C.; Hester, A.; Czogalla, B.; Mahner, S.; Rottmann, M.; Mayr, D.; Schmoeckel, E.; et al. The G-Protein-Coupled Estrogen Receptor (GPER) Regulates Trimethylation of Histone H3 at Lysine 4 and Represses Migration and Proliferation of Ovarian Cancer Cells In Vitro. Cells 2021, 10, 619. [CrossRef]

112. Yan, Y.; Liu, H.; Wen, H.; Jiang, X.; Cao, X.; Zhang, G.; Liu, G. The novel estrogen receptor GPER regulates the migration and invasion of ovarian cancer cells. Mol. Cell. Biochem. 2013, 378, 1-7. [CrossRef]

113. Liu, H.; Yan, Y.; Wen, H.; Jiang, X.; Cao, X.; Zhang, G.; Liu, G. A novel estrogen receptor GPER mediates proliferation induced by 17 $\beta$-estradiol and selective GPER agonist G-1 in estrogen receptor $\alpha(\mathrm{ER} \alpha)$-negative ovarian cancer cells. Cell Biol. Int. 2014, 38, 631-638. [CrossRef] [PubMed]

114. Yan, Y.; Jiang, X.; Zhao, Y.; Wen, H.; Liu, G. Role of GPER on proliferation, migration and invasion in ligand-independent manner in human ovarian cancer cell line SKOV3. Cell Biochem. Funct. 2015, 33, 552-559. [CrossRef] [PubMed]

115. Lin, B.C.; Suzawa, M.; Blind, R.; Tobias, S.C.; Bulun, S.E.; Scanlan, T.S.; Ingraham, H.A. Stimulating the GPR30 Estrogen Receptor with a Novel Tamoxifen Analogue Activates SF-1 and Promotes Endometrial Cell Proliferation. Cancer Res. 2009, 69, 5415-5423. [CrossRef] [PubMed]

116. Vivacqua, A.; Romeo, E.; De Marco, P.; De Francesco, E.M.; Abonante, S.; Maggiolini, M. GPER mediates the Egr-1 expression induced by $17 \beta$-estradiol and 4-hydroxitamoxifen in breast and endometrial cancer cells. Breast Cancer Res. Treat. 2011, 133, 1025-1035. [CrossRef]

117. Filigheddu, N.; Sampietro, S.; Chianale, F.; Porporato, P.E.; Gaggianesi, M.; Gregnanin, I.; Rainero, E.; Ferrara, M.; Perego, B.; Riboni, F.; et al. Diacylglycerol kinase $\alpha$ mediates $17-\beta$-estradiol-induced proliferation, motility, and anchorage-independent growth of Hec-1A endometrial cancer cell line through the G protein-coupled estrogen receptor GPR30. Cell. Signal. 2011, 23, 1988-1996. [CrossRef]

118. Deng, J.; Wang, W.; Yu, G.; Ma, X. MicroRNA-195 inhibits epithelial-mesenchymal transition by targeting G protein-coupled estrogen receptor 1 in endometrial carcinoma. Mol. Med. Rep. 2019, 20, 4023-4032. [CrossRef]

119. Zhang, H.; Wang, X.; Chen, Z.; Wang, W. MicroRNA-424 suppresses estradiol-induced cell proliferation via targeting GPER in endometrial cancer cells. Cell. Mol. Boil. 2015, 61, 96-101.

120. Lau, K.-M.; Ma, F.M.-T.; Xia, J.T.; Chan, Q.K.Y.; Ng, C.-F.; To, K.-F. Activation of GPR30 stimulates GTP-binding of Gai1 protein to sustain activation of Erk1/2 in inhibition of prostate cancer cell growth and modulates metastatic properties. Exp. Cell Res. 2017, 350, 199-209. [CrossRef]

121. Chimento, A.; De Luca, A.; Nocito, M.C.; Avena, P.; La Padula, D.; Zavaglia, L.; Pezzi, V. Role of GPER-Mediated Signaling in Testicular Functions and Tumorigenesis. Cells 2020, 9, 2115. [CrossRef]

122. Chevalier, N.; Hinault, C.; Clavel, S.; Paul-Bellon, R.; Fenichel, P. GPER and Testicular Germ Cell Cancer. Front. Endocrinol. 2021, 11, 1084. [CrossRef]

123. Kotula-Balak, M.; Gorowska-Wojtowicz, E.; Milon, A.; Pawlicki, P.; Tworzydlo, W.; Płachno, B.J.; Krakowska, I.; Hejmej, A.; Wolski, J.K.; Bilinska, B. Towards understanding leydigioma: Do G protein-coupled estrogen receptor and peroxisome proliferator-activated receptor regulate lipid metabolism and steroidogenesis in Leydig cell tumors? Protoplasma 2020, 257, 1149-1163. [CrossRef] [PubMed]

124. Börjesson, S.I.; Elinder, F. Structure, Function, and Modification of the Voltage Sensor in Voltage-Gated Ion Channels. Cell Biophys. 2008, 52, 149-174. [CrossRef] [PubMed]

125. Fiske, J.L.; Fomin, V.P.; Brown, M.L.; Duncan, R.L.; Sikes, R.A. Voltage-sensitive ion channels and cancer. Cancer Metastasis Rev. 2006, 25, 493-500. [CrossRef]

126. Jean-Yves, L.; Halima, O.-A.; Olivier, S.; Pierre, B.; Ahmed, A.; Christophe, V. Voltage-Gated Ion Channels, New Targets in Anti-Cancer Research. Recent Pat. Anti-Cancer Drug Discov. 2007, 2, 189-202. [CrossRef] 
127. Shan, B.; Dong, M.; Tang, H.; Wang, N.; Zhang, J.; Yan, C.; Jiao, X.; Zhang, H.; Wang, C. Voltage-gated sodium channels were differentially expressed in human normal prostate, benign prostatic hyperplasia and prostate cancer cells. Oncol. Lett. 2014, 8, 345-350. [CrossRef]

128. Wang, Z.; Gao, R.; Shen, Y.; Cai, J.; Lei, M.; Wang, L.-Y. Expression of voltage-gated sodium channel $\alpha$ subunit in human ovarian cancer. Oncol. Rep. 2010, 23, 1293-1299. [CrossRef] [PubMed]

129. Kow, L.-M.; Pfaff, D.W. Rapid estrogen actions on ion channels: A survey in search for mechanisms. Steroids 2016, 111, 46-53. [CrossRef]

130. Sula, A.; Hollingworth, D.; Ng, L.C.; Larmore, M.; DeCaen, P.G.; Wallace, B. A tamoxifen receptor within a voltage-gated sodium channel. Mol. Cell 2021, 81, 1160-1169. [CrossRef]

131. Thomas, P.; Pang, Y.; Dong, J.; Groenen, P.; Kelder, J.; De Vlieg, J.; Zhu, Y.; Tubbs, C. Steroid and G Protein Binding Characteristics of the Seatrout and Human Progestin Membrane Receptor $\alpha$ Subtypes and Their Evolutionary Origins. Endocrinology 2007, 148, 705-718. [CrossRef] [PubMed]

132. Ryu, C.S.; Klein, K.; Zanger, U.M. Membrane Associated Progesterone Receptors: Promiscuous Proteins with Pleiotropic Functions-Focus on Interactions with Cytochromes P450. Front. Pharmacol. 2017, 8, 159. [CrossRef]

133. Zhu, Y.; Bond, J.; Thomas, P. Identification, classification, and partial characterization of genes in humans and other vertebrates homologous to a fish membrane progestin receptor. Proc. Natl. Acad. Sci. USA 2003, 100, 2237-2242. [CrossRef] [PubMed]

134. Thomas, P. characteristics of membrane progesterone alpha (mPR?) and progesterone membrane receptor component 1 (PGMRC1) and their roles in mediating rapid progestin actions. Front. Neuroendocrinol. 2008, 29, 292-312. [CrossRef]

135. Pang, Y.; Dong, J.; Thomas, P. Characterization, Neurosteroid Binding and Brain Distribution of Human Membrane Progesterone Receptors $\delta$ and $\epsilon(\mathrm{mPR} \delta$ and $\mathrm{mPR} \epsilon)$ and $\mathrm{mPR} \delta$ Involvement in Neurosteroid Inhibition of Apoptosis. Endocrinology 2013, 154, 283-295. [CrossRef]

136. Dosiou, C.; Hamilton, A.E.; Pang, Y.; Overgaard, M.T.; Tulac, S.; Dong, J.; Thomas, P.; Guidice, L.C. Expression of membrane proges-terone receptors (mPRs) on human $\mathrm{T}$ lymphocytes and Jurkat cells and activation of $\mathrm{G}$ proteins by progesterone. $J$. Endocrinol. 2008, 196, 67-77. [CrossRef] [PubMed]

137. Dressing, G.E.; Thomas, P. Identification of membrane progestin receptors in human breast cancer cell lines and biopsies and their potential involvement in breast cancer. Steroids 2007, 72, 111-116. [CrossRef] [PubMed]

138. Pang, Y.F.; Thomas, P. Progesterone signals through membrane progesterone receptors (mPRs) in MDA-MB-468 and mPRtransfected MDA-MB-231 breast cancer cells which lack full-length and C-terminal truncated isoforms of the nuclear progesterone receptor. Steroids 2011, 76, 921-928. [CrossRef] [PubMed]

139. Zuo, L.; Li, W.; You, S. Progesterone reverses the mesenchymal phenotypes of basal phenotype breast cancer cells by a mem-brane progesterone receptor alpha mediated pathway. Breast Cancer Res. 2010, 12, R34. [CrossRef] [PubMed]

140. Charles, N.A.; Thomas, P.; Lange, C.A. Signaling events mediated by membrane progesterone receptors (mPRs) in ovarian cancer cells. Horm. Cancer 2010, 1, 167-176. [CrossRef]

141. Wu, X.; Sun, L.; Wang, X.; Su, P.; Li, Z.; Zhang, C.; Wang, Y.; Gao, P.; Ma, R. Breast Cancer Invasion and Metastasis by mPR $\alpha$ Through the PI3K/Akt Signaling Pathway. Pathol. Oncol. Res. 2015, 22, 471-476. [CrossRef]

142. Xie, M.; Zhu, X.; Liu, Z.; Shrubsole, M.; Varma, V.; Mayer, I.A.; Dai, Q.; Chen, Q.; You, S. Membrane Progesterone Receptor Alpha as a Potential Prognostic Biomarker for Breast Cancer Survival: A Retrospective Study. PLoS ONE 2012, 7, e35198. [CrossRef]

143. Dressing, G.E.; Alyea, R.; Pang, Y.; Thomas, P. Membrane Progesterone Receptors (mPRs) Mediate Progestin Induced Antimorbidity in Breast Cancer Cells and Are Expressed in Human Breast Tumors. Horm. Cancer 2012, 3, 101-112. [CrossRef]

144. Zhang, J.; Hu, J.; Li, W.; Zhang, C.; Su, P.; Wang, Y.; Sun, W.; Wang, X.; Li, L.; Wu, X. Rapamycin Antagonizes BCRP-Mediated Drug Resistance Through the PI3K/Akt/mTOR Signaling Pathway in mPR $\alpha$-Positive Breast Cancer. Front. Oncol. 2021, 11. [CrossRef]

145. Zhou, L.; Zhou, W.; Zhang, H.; Hu, Y.; Yu, L.; Zhang, Y.; Zhang, Y.; Wang, S.; Wang, P.; Xia, W. Progesterone suppresses triple-negative breast cancer growth and metastasis to the brain via membrane progesterone receptor $\alpha$. Int. J. Mol. Med. 2017, 40, 755-761. [CrossRef] [PubMed]

146. Xie, M.; Zhou, L.; Chen, X.; Gainey, L.O.; Xiao, J.; Nanes, M.S.; Hou, A.; You, S.; Chen, Q. Progesterone and Src Family Inhibitor PP1 Synergistically Inhibit Cell Migration and Invasion of Human Basal Phenotype Breast Cancer Cells. BioMed Res. Int. 2015, 2015, 1-14. [CrossRef]

147. Romero-Sánchez, M.; Peiper, S.C.; Evans, B.; Wang, Z.; Catasús, L.; Ribe, A.; Prat, J.; Giri, J.G. Expression profile of heptahelical putative membrane progesterone receptors in epithelial ovarian tumors. Hum. Pathol. 2008, 39, 1026-1033. [CrossRef]

148. Charles, N.J.; Thomas, P.; Lange, C.A. Expression of Membrane Progesterone Receptors (mPR/PAQR) in Ovarian Cancer Cells: Implications for Progesterone-Induced Signaling Events. Horm. Cancer 2010, 1, 167-176. [CrossRef]

149. Sinreih, M.; Knific, T.; Thomas, P.; Grazio, S.F.; Rižner, T.L. Membrane progesterone receptors $\beta$ and $\gamma$ have potential as prognostic biomarkers of endometrial cancer. J. Steroid Biochem. Mol. Biol. 2018, 178, 303-311. [CrossRef]

150. Li, B.; Lin, Z.; Liang, Q.; Hu, Y.; Xu, W.-F. PAQR6 expression enhancement suggests a worse prognosis in prostate cancer patients. Open Life Sci. 2018, 13, 511-517. [CrossRef] [PubMed]

151. Kimura, I.; Nakayama, Y.; Konishi, M.; Terasawa, K.; Ohta, M.; Itoh, N.; Fujimoto, M. Functions of MAPR (membrane-associated progesterone receptor) family members as heme/steroid-binding proteins. Curr. Protein Pept. Sci. 2012, 13, 687-696. [CrossRef] 
152. Ruan, X.; Zhang, Y.; Mueck, A.O.; Willibald, M.; Seeger, H.; Fehm, T.; Brucker, S.; Neubauer, H. Increased expression of progesterone receptor membrane component 1 is associated with aggressive phenotype and poor prognosis in ER-positive and negative breast cancer. Menopause 2017, 24, 203-209. [CrossRef] [PubMed]

153. Lin, S.-T.; May, E.W.S.; Chang, J.-F.; Hu, R.-Y.; Wang, L.H.-C.; Chan, H.-L. PGRMC1 contributes to doxorubicin-induced chemoresistance in MES-SA uterine sarcoma. Cell. Mol. Life Sci. 2015, 72, 2395-2409. [CrossRef]

154. Kim, J.Y.; Kim, S.Y.; Choi, H.S.; Kim, M.K.; Lee, H.M.; Jang, Y.-J.; Ryu, C.J. Progesterone Receptor Membrane Component 1 suppresses the 553 and $\mathrm{Wnt} / \beta$-catenin pathways to promote human pluripotent stem cell self-renewal. Sci. Rep. 2018, 8, 1-16. [CrossRef]

155. Thejer, B.M.; Adhikary, P.P.; Kaur, A.; Teakel, S.L.; Van Oosterum, A.; Seth, I.; Pajic, M.; Hannan, K.M.; Pavy, M.; Poh, P.; et al. PGRMC1 phosphorylation affects cell shape, motility, glycolysis, mitochondrial form and function, and tumor growth. BMC Mol. Cell Biol. 2020, 21, 1-24. [CrossRef]

156. Neubauer, H.; Ma, Q.; Zhou, J.; Yu, Q.; Ruan, X.; Seeger, H.; Fehm, T.; Mueck, A.O. Possible role of PGRMC1 in breast cancer development. Climacteric 2013, 16, 509-513. [CrossRef]

157. Ahmed, I.S.; Rohe, H.J.; Twist, K.E.; Mattingly, M.N.; Craven, R.J. Progesterone Receptor Membrane Component 1 (Pgrmc1): A Heme-1 Domain Protein That Promotes Tumorigenesis and Is Inhibited by a Small Molecule. J. Pharmacol. Exp. Ther. 2010, 333, 564-573. [CrossRef] [PubMed]

158. Ji, S.; Wu, A.; Yang, H. Expression of progesterone receptor membrane component-1 is associated with the malignant pheno-types of breast cancer. Nan Fang Yi Ke Da Xue Xue Bao 2012, 32, 635-638.

159. Cai, G.; Yang, X.; Ruan, X.; Wang, J.; Fang, Y.; Wei, Y.; Zhang, Y.; Gu, M.; Mueck, A.O. Association of circulating Progesterone Receptor Membrane Component-1 (PGRMC1) with PGRMC1 expression in breast tumour tissue and with clinical breast tumour characteristics. Maturitas 2020, 140, 64-71. [CrossRef]

160. Ruan, X.; Cai, G.; Wei, Y.; Gu, M.; Zhang, Y.; Zhao, Y.; Mueck, A.O. Association of circulating Progesterone Receptor Membrane Component-1 (PGRMC1) with breast tumor characteristics and comparison with known tumor markers. Menopause 2020, 27, 183-193. [CrossRef]

161. Clark, N.C.; Friel, A.; Pru, C.A.; Zhang, L.; Shioda, T.; Rueda, B.R.; Peluso, J.J.; Pru, J.K. Progesterone receptor membrane component 1 promotes survival of human breast cancer cells and the growth of xenograft tumors. Cancer Biol. Ther. 2016, 17, 262-271. [CrossRef]

162. Neubauer, H.; Adam, G.; Seeger, H.; Mueck, A.O.; Solomayer, E.; Wallwiener, D.; Cahill, M.; Fehm, T. Membrane-initiated effects of progesterone on proliferation and activation of VEGF in breast cancer cells. Climacteric 2009, 12, 230-239. [CrossRef] [PubMed]

163. Lee, S.R.; Lee, Y.H.; Jo, S.L.; Heo, J.H.; Kim, G.; Lee, G.-S.; An, B.-S.; Baek, I.-J.; Hong, E.-J. Absence of progesterone receptor membrane component 1 reduces migration and metastasis of breast cancer. Cell Commun. Signal. 2021, 19, 1-11. [CrossRef]

164. Gu, M.; Wang, L.; Yang, C.; Li, X.; Jia, C.; Croteau, S.; Ruan, X.; Hardy, P. Micro-RNA-181a suppresses progestin-promoted breast cancer cell growth. Maturitas 2018, 114, 60-66. [CrossRef]

165. Cantonero, C.; Salido, G.M.; Rosado, J.A.; Redondo, P.C. PGRMC1 Inhibits Progesterone-Evoked Proliferation and Ca ${ }^{2+}$ Entry Via STIM2 in MDA-MB-231 Cells. Int. J. Mol. Sci. 2020, 21, 7641. [CrossRef]

166. Pedroza, D.A.; Rajamanickam, V.; Subramani, R.; Bencomo, A.; Galvez, A.; Lakshmanaswamy, R. Progesterone receptor membrane component 1 promotes the growth of breast cancers by altering the phosphoproteome and augmenting EGFR/PI3K/AKT signalling. Br. J. Cancer 2020, 123, 1326-1335. [CrossRef] [PubMed]

167. Asperger, H.; Stamm, N.; Gierke, B.; Pawlak, M.; Hofmann, U.; Zanger, U.M.; Marton, A.; Katona, R.L.; Buhala, A.; Vizler, C.; et al. Progesterone receptor membrane component 1 regulates lipid homeostasis and drives oncogenic signaling resulting in breast cancer progression. Breast Cancer Res. 2020, 22, 1-16. [CrossRef]

168. Pedroza, D.A.; Subramani, R.; Tiula, K.; Do, A.; Rashiraj, N.; Galvez, A.; Chatterjee, A.; Bencomo, A.; Rivera, S.; Lakshmanaswamy, R. Crosstalk between progesterone receptor membrane component 1 and estrogen receptor $\alpha$ promotes breast cancer cell proliferation. Lab. Investig. 2021, 101, 733-744. [CrossRef]

169. Ponikwicka-Tyszko, D.; Chrusciel, M.; Pulawska, K.; Bernaczyk, P.; Sztachelska, M.; Guo, P.; Li, X.; Toppari, J.; Huhtaniemi, I.T.; Wolczynski, S.; et al. Mifepristone Treatment Promotes Testicular Leydig Cell Tumor Progression in Transgenic Mice. Cancers 2020, 12, 3263. [CrossRef]

170. Friel, A.; Zhang, L.; Pru, C.A.; Clark, N.C.; McCallum, M.L.; Blok, L.J.; Shioda, T.; Peluso, J.J.; Rueda, B.R.; Pru, J.K. Progesterone receptor membrane component 1 deficiency attenuates growth while promoting chemosensitivity of human endometrial xenograft tumors. Cancer Lett. 2015, 356, 434-442. [CrossRef]

171. Peluso, J.J. Progesterone signaling mediated through progesterone receptor membrane component- 1 in ovarian cells with special emphasis on ovarian cancer. Steroids 2011, 76, 903-909. [CrossRef]

172. Zhu, X.; Han, Y.; Fang, Z.; Wu, W.; Ji, M.; Teng, F.; Zhu, W.; Yang, X.; Jia, X.; Zhang, C. Progesterone protects ovarian cancer cells from cisplatin-induced inhibitory effects through progesterone receptor membrane component $1 / 2$ as well as AKT signaling. Oncol. Rep. 2013, 30, 2488-2494. [CrossRef] [PubMed]

173. Hasegawa, S.; Kasubuchi, M.; Terasawa, K.; Kimura, I. Perspectives on Membrane-associated Progesterone Receptors as Prospective Therapeutic Targets. Curr. Drug Targets 2016, 17, 1189-1197. [CrossRef] 
174. Schwickert, A.; Weghake, E.; Brüggemann, K.; Engbers, A.; Brinkmann, B.; Kemper, B.; Seggewiß, J.; Stock, C.; Ebnet, K.; Kiesel, L.; et al. microRNA miR-142-3p Inhibits Breast Cancer Cell Invasiveness by Synchronous Targeting of WASL, Integrin Alpha V, and Additional Cytoskeletal Elements. PLoS ONE 2015, 10, e0143993. [CrossRef] [PubMed]

175. Fahlén, M.; Zhang, H.; Lofgren, L.; Masironi, B.; Von Schoultz, E.; Von Schoultz, B.; Sahlin, L. Expression of Progesterone and Androgen Receptors in the Breast of Premenopausal Women, Considering Menstrual Phase. Anticancer. Res. 2018, 38, 1499-1510. [CrossRef]

176. Causey, M.W.; Huston, L.J.; Harold, D.M.; Charaba, C.J.; Ippolito, D.L.; Hoffer, Z.S.; Brown, T.A.; Stallings, J. Transcriptional Analysis of Novel Hormone Receptors PGRMC1 and PGRMC2 as Potential Biomarkers of Breast Adenocarcinoma Staging. J. Surg. Res. 2011, 171, 615-622. [CrossRef]

177. Albrecht, C.; Huck, V.; Wehling, M.; Wendler, A. In vitro inhibition of SKOV-3 cell migration as a distinctive feature of progesterone receptor membrane component type 2 versus type. Steroids 2012, 77, 1543-1550. [CrossRef]

178. Han, K.-H.; Lee, S.-H.; Ha, S.-A.; Kim, H.K.; Lee, C.; Kim, D.-H.; Gong, K.H.; Yoo, J.; Kim, S.; Kim, J.W. The functional and structural characterization of a novel oncogene GIG47 involved in the breast tumorigenesis. BMC Cancer 2012, 12, 274. [CrossRef]

179. Ohta, H.; Kimura, I.; Konishi, M.; Itoh, N. Neudesin as a unique secreted protein with multi-functional roles in neural functions, energy metabolism, and tumorigenesis. Front. Mol. Biosci. 2015, 2, 24. [CrossRef]

180. Bruce, A.; Rybak, A.P. CYB5D2 Requires Heme-Binding to Regulate HeLa Cell Growth and Confer Survival from Chemotherapeutic Agents. PLoS ONE 2014, 9, e86435. [CrossRef]

181. Xie, Y.; Shen, Y.T.; Kapoor, A.; Ojo, D.; Wei, F.; De Melo, J.; Lin, X.; Wong, N.; Yan, J.; Tao, L.; et al. CYB5D2 displays tumor suppression activities towards cervical cancer. Biochim. Biophys. Acta Mol. Basis Dis. 2016, 1862, 556-565. [CrossRef]

182. Thomas, P.; Dong, J. Novel mechanism of endocrine disruption by fungicides through binding to the membrane androgen receptor, ZIP9 (SLC39A9), and antagonizing rapid testosterone induction of the intrinsic apoptotic pathway. Steroids 2019, 149, 108415. [CrossRef] [PubMed]

183. Périan, S.; Vanacker, J.-M. GPER as a Receptor for Endocrine-Disrupting Chemicals (EDCs). Front. Endocrinol. 2020, 11, 545. [CrossRef] [PubMed]

184. Qie, Y.; Qin, W.; Zhao, K.; Liu, C.; Zhao, L.; Guo, L.-H. Environmental Estrogens and Their Biological Effects through GPER Mediated Signal Pathways. Environ. Pollut. 2021, 278, 116826. [CrossRef]

185. Pupo, M.; Pisano, A.; Lappano, R.; Santolla, M.F.; De Francesco, E.M.; Abonante, S.; Rosano, C.; Maggiolini, M. Bisphenol A Induces Gene Expression Changes and Proliferative Effects through GPER in Breast Cancer Cells and Cancer-Associated Fibroblasts. Environ. Health Perspect. 2012, 120, 1177-1182. [CrossRef]

186. Xu, F.; Wang, X.; Wu, N.; He, S.; Yi, W.; Xiang, S.; Zhang, P.; Xie, X.; Ying, C. Bisphenol A induces proliferative effects on both breast cancer cells and vascular endothelial cells through a shared GPER-dependent pathway in hypoxia. Environ. Pollut. 2017, 231, 1609-1620. [CrossRef]

187. Cao, L.; Ren, X.-M.; Liang-Hong, G.; Zhang, J.; Qin, W.-P.; Yang, Y.; Wan, B.; Guo, L.-H. Bisphenol AF and Bisphenol B Exert Higher Estrogenic Effects than Bisphenol A via G Protein-Coupled Estrogen Receptor Pathway. Environ. Sci. Technol. 2017, 51, 11423-11430. [CrossRef] [PubMed]

188. Deng, Q.; Jiang, G.; Wu, Y.; Li, J.; Liang, W.; Chen, L.; Su, Q.; Li, W.; Du, J.; Wong, C.K.; et al. GPER/Hippo-YAP signal is involved in Bisphenol $\mathrm{S}$ induced migration of triple negative breast cancer (TNBC) cells. J. Hazard. Mater. 2018, 355, 1-9. [CrossRef]

189. Lei, B.; Sun, S.; Zhang, X.; Feng, C.; Xu, J.; Wen, Y.; Huang, Y.; Wu, M.; Yu, Y. Bisphenol AF exerts estrogenic activity in MCF-7 cells through activation of Erk and PI3K/Akt signals via GPER signaling pathway. Chemosphere 2019, 220, 362-370. [CrossRef]

190. Lei, B.; Tang, Q.; Sun, S.; Zhang, X.; Huang, Y.; Xu, L. Insight into the mechanism of tetrachlorobisphenol A (TCBPA)-induced proliferation of breast cancer cells by GPER-mediated signaling pathways. Environ. Pollut. 2021, 275, 116636. [CrossRef]

191. Castillo-Sanchez, R.; Ramirez-Ricardo, J.; Martinez-Baeza, E.; Cortes-Reynosa, P.; Candanedo-Gonzales, F.; Gomez, R.; Salazar, E.P. Bisphenol A induces focal adhesions assembly and activation of FAK, Src and ERK2 via GPER in MDA-MB-231 breast cancer cells. Toxicol. Vitr. 2020, 66, 104871. [CrossRef]

192. Chevalier, N.; Bouskine, A.; Fenichel, P. Bisphenol A promotes testicular seminoma cell proliferation through GPER/GPR. Int. J. Cancer 2012, 130, 241-242. [CrossRef] [PubMed]

193. Gorowska-Wojtowicz, E.; Duliban, M.; Kudrycka, M.; Dutka, P.; Pawlicki, P.; Milon, A.; Zarzycka, M.; Placha, W.; Kotula-Balak, M.; Ptak, A.; et al. Leydig cell tumorigenesis-Implication of G-protein coupled membrane estrogen receptor, peroxisome proliferatoractivated receptor and xenoestrogen exposure. In vivo and in vitro appraisal. Tissue Cell 2019, 61, 51-60. [CrossRef]

194. Buoso, E.; Masi, M.; Galbiati, V.; Maddalon, A.; Iulini, M.; Kenda, M.; Dolenc, M.S.; Marinovich, M.; Racchi, M.; Corsini, E. Effect of estrogen-active compounds on the expression of RACK1 and immunological implications. Arch. Toxicol. 2020, 94, $2081-2095$. [CrossRef]

195. Buoso, E.; Kenda, M.; Masi, M.; Linciano, P.; Galbiati, V.; Racchi, M.; Dolenc, M.S.; Corsini, E. Effects of Bisphenols on RACK1 Expression and Their Immunological Implications in THP-1 Cells. Front. Pharmacol. 2021, 12, 2585. [CrossRef]

196. Racchi, M.; Buoso, E.; Ronfani, M.; Serafini, M.M.; Galasso, M.; Lanni, C.; Corsini, E. Role of Hormones in the Regulation of RACK1 Expression as a Signaling Checkpoint in Immunosenescence. Int. J. Mol. Sci. 2017, 18, 1453. [CrossRef]

197. Greten, F.R.; Grivennikov, S.I. Inflammation and Cancer: Triggers, Mechanisms, and Consequences. Immunity 2019, 51, $27-41$. [CrossRef] 
198. Cirillo, F.; Lappano, R.; Bruno, L.; Rizzuti, B.; Grande, F.; Guzzi, R.; Briguori, S.; Miglietta, A.M.; Nakajima, M.; Di Martino, M.T.; et al. AHR and GPER mediate the stimulatory effects induced by 3-methylcholanthrene in breast cancer cells and cancer-associated fibroblasts (CAFs). J. Exp. Clin. Cancer Res. 2019, 38, 1-18. [CrossRef]

199. Tokumoto, T.; Tokumoto, M.; Thomas, P. Interactions of Diethylstilbestrol (DES) and DES Analogs with Membrane Progestin Receptor- $\alpha$ and the Correlation with Their Nongenomic Progestin Activities. Endocrinology 2007, 148, 3459-3467. [CrossRef]

200. Seeger, H.; Ruan, X.; Neubauer, H.; Brucker, S.; Mueck, A.O. Membrane-initiated effects of Serelys®on proliferation and apoptosis of human breast cancer cells. Gynecol. Endocrinol. 2018, 34, 353-356. [CrossRef]

201. Li, X.; Ruan, X.; Gu, M.; Mueck, A.O. PGRMC1 can trigger estrogen-dependent proliferation of breast cancer cells: Estradiol vs. equilin vs. ethinylestradiol. Climacteric 2019, 22, 483-488. [CrossRef]

202. Neubauer, H.; Yang, Y.; Seeger, H.; Fehm, T.; Cahill, M.A.; Tong, X.; Ruan, X.; Mueck, A.O. The presence of a membrane-bound progesterone receptor sensitizes the estradiol-induced effect on the proliferation of human breast cancer cells. Menopause 2011, 18, 845-850. [CrossRef]

203. Izquierdo, C.; Martín-Martínez, M.; Gómez-Monterrey, I.; González-Muñiz, R. TRPM8 Channels: Advances in Structural Studies and Pharmacological Modulation. Int. J. Mol. Sci. 2021, 22, 8502. [CrossRef]

204. Rouhimoghadam, M.; Lu, A.S.; Salem, A.K.; Filardo, E.J. Therapeutic Perspectives on the Modulation of G-Protein Coupled Estrogen Receptor, GPER, Function. Front. Endocrinol. 2020, 11, 591217. [CrossRef]

205. Thomas, P.; Dong, J. (-)-Epicatechin acts as a potent agonist of the membrane androgen receptor, ZIP9 (SLC39A9), to promote apoptosis of breast and prostate cancer cells. J. Steroid Biochem. Mol. Biol. 2021, 211, 105906. [CrossRef]

206. Bulldan, A.; Malviya, V.N.; Upmanyu, N.; Konrad, L.; Scheiner-Bobis, G. Testosterone/bicalutamide antagonism at the predicted extracellular androgen binding site of ZIP9. Biochim. Biophys. Acta Bioenerg. 2017, 1864, 2402-2414. [CrossRef]

207. Stepniewski, T.M.; Torrens-Fontanals, M.; Rodríguez-Espigares, I.; Giorgino, T.; Primdahl, K.G.; Vik, A.; Stenstrøm, Y.; Selent, J.; Hansen, T.V. Synthesis, molecular modelling studies and biological evaluation of new oxoeicosanoid receptor 1 agonists. Bioorg. Med. Chem. 2018, 26, 3580-3587. [CrossRef]

208. Chourey, S.; Ye, Q.; Reddy, C.N.; Cossette, C.; Gravel, S.; Zeller, M.; Slobodchikova, I.; Vuckovic, D.; Rokach, J.; Powell, W.S. In vivo $\alpha$-hydroxylation of a 2-alkylindole antagonist of the OXE receptor for the eosinophil chemoattractant 5-oxo-6,8,11,14eicosatetraenoic acid in monkeys. Biochem. Pharmacol. 2017, 138, 107-118. [CrossRef]

209. Cossette, C.; Chourey, S.; Ye, Q.; Reddy, C.N.; Gore, V.; Gravel, S.; Slobodchikova, I.; Vuckovic, D.; Rokach, J.; Powell, W.S. Pharmacokinetics and Metabolism of Selective Oxoeicosanoid (OXE) Receptor Antagonists and Their Effects on 5-Oxo-6,8,11,14eicosatetraenoic Acid (5-Oxo-ETE)-Induced Granulocyte Activation in Monkeys. J. Med. Chem. 2016, 59, 10127-10146. [CrossRef]

210. Ye, Q.; Chourey, S.; Reddy, C.N.; Wang, R.; Cossette, C.; Gravel, S.; Slobodchikova, I.; Vuckovic, D.; Rokach, J.; Powell, W.S. Novel highly potent OXE receptor antagonists with prolonged plasma lifetimes that are converted to active metabolites in vivo in monkeys. Br. J. Pharmacol. 2020, 177, 388-401. [CrossRef]

211. Chourey, S.; Ye, Q.; Reddy, C.N.; Wang, R.; Cossette, C.; Gravel, S.; Slobodchikova, I.; Vuckovic, D.; Rokach, J.; Powell, W.S. Novel Highly Potent and Metabolically Resistant Oxoeicosanoid (OXE) Receptor Antagonists That Block the Actions of the Granulocyte Chemoattractant 5-Oxo-6,8,11,14-Eicosatetraenoic Acid (5-oxo-ETE). J. Med. Chem. 2018, 61, 5934-5948. [CrossRef]

212. Reddy, C.N.; Alhamza, H.; Chourey, S.; Ye, Q.; Gore, V.; Cossette, C.; Gravel, S.; Slobodchikova, I.; Vuckovic, D.; Rokach, J.; et al. Metabolism and pharmacokinetics of a potent $\mathrm{N}$-acylindole antagonist of the OXE receptor for the eosinophil chemoattractant 5-oxo-6,8,11,14-eicosatetraenoic acid (5-oxo-ETE) in rats and monkeys. Eur. J. Pharm. Sci. 2018, 115, 88-99. [CrossRef]

213. Pi, M.; Kapoor, K.; Ye, R.; Hwang, D.-J.; Miller, D.D.; Smith, J.C.; Baudry, J.; Quarles, L.D. Computationally identified novel agonists for GPRC6A. PLoS ONE 2018, 13, e0195980. [CrossRef]

214. Ishida, Y.; Kitayama, K.; Hanada, K.; Shibutani, S.; Nishizaki, K.; Kinjo, T.; Endo, T.; Suzuki, A.; Tateyama, S.; Nishizaki, F.; et al. Diltiazem Inhibits Coronary Spasm via Inhibition of Cav1.2Phosphorylation and Protein Kinase C Activation in a Mouse Model of Coronary Spastic Angina. Int. Hearth J. 2021, 62, 910-918. [CrossRef]

215. Borella, G.; Da Ros, A.; Borile, G.; Porcù, E.; Tregnago, C.; Benetton, M.; Marchetti, A.; Bisio, V.; Montini, B.; Michielotto, B.; et al. Targeting mesenchymal stromal cells plasticity to reroute acute myeloid leukemia course. Blood 2021, 138, 7. [CrossRef]

216. Chen, H.; Vandorpe, D.H.; Xie, X.; Alper, S.L.; Zeidel, M.L.; Yu, W. Disruption of Cav1.2-mediated signaling is a pathway for ketamine-induced pathology. Nat. Commun. 2020, 11, 4328. [CrossRef]

217. Fusi, F.; Trezza, A.; Sgaragli, G.; Spiga, O.; Saponara, S.; Bova, S. Ritanserin blocks CaV1.2 channels in rat artery smooth muscles: Electrophysiological, functional, and computational studies. Acta Pharmacol. Sin. 2020, 41, 1158-1166. [CrossRef]

218. Yarotskyy, V.; Gao, G.; Du, L.; Ganapathi, S.B.; Peterson, B.Z.; Elmslie, K. Roscovitine Binds to Novel L-channel (CaV1.2) Sites That Separately Affect Activation and Inactivation. J. Biol. Chem. 2010, 285, 43-53. [CrossRef]

219. Lee, J.-H.; Liu, J.; Shin, M.; Hong, M.; Nah, S.-Y.; Bae, H. Metergoline inhibits the neuronal Nav1.2 voltage-dependent Na+ channels expressed in Xenopus oocytes. Acta Pharmacol. Sin. 2014, 35, 862-868. [CrossRef]

220. Peters, C.; Sokolov, S.; Rajamani, S.; Ruben, P. Effects of the antianginal drug, ranolazine, on the brain sodium channel NaV1.2 and its modulation by extracellular protons. Br. J. Pharmacol. 2013, 169, 704-716. [CrossRef]

221. Rivara, M.; Baheti, A.R.; Fantini, M.; Cocconcelli, G.; Ghiron, C.; Kalmar, C.L.; Singh, N.; Merrick, E.C.; Patel, M.K.; Zuliani, V. 2,4(5)-Diarylimidazoles: Synthesis and biological evaluation of a new class of sodium channel blockers against hNav1.2. Bioorg. Med. Chem. Lett. 2008, 18, 5460-5462. [CrossRef] 
222. Xiao, J.; Chen, X.; Lu, X.; Xie, M.; He, B.; He, S.; You, S.; Chen, Q. Progesterone/Org inhibits lung adenocarcinoma cell growth via membrane progesterone receptor alpha. Thorac. Cancer 2020, 11, 2209-2223. [CrossRef]

223. Thomas, P.; Pang, Y. Anti-apoptotic Actions of Allopregnanolone and Ganaxolone Mediated Through Membrane Progesterone Receptors (PAQRs) in Neuronal Cells. Front. Endocrinol. 2020, 11, 417. [CrossRef] [PubMed]

224. Wang-Eckhardt, L.; Eckhardt, M. A progesterone receptor membrane component 1 antagonist induces large vesicles independent of progesterone receptor membrane component 1 expression. Biol. Chem. 2020, 401, 1093-1099. [CrossRef] [PubMed]

225. Teakel, S.L.; Ludescher, M.; Thejer, B.M.; Poschmann, G.; Forwood, J.K.; Neubauer, H.; Cahill, M.A. Protein complexes including PGRMC1 and actin-associated proteins are disrupted by AG-205. Biochem. Biophys. Res. Commun. 2020, 524, 64-69. [CrossRef] [PubMed]

226. Will, E.A.; Liu, X.; Peluso, J.J. AG 205, a progesterone receptor membrane component 1 antagonist, ablates progesterone's ability to block oxidative stress-induced apoptosis of human granulosa/luteal cells. Biol. Reprod. 2017, 96, 843-854. [CrossRef]

227. D'Arrigo, G.; Gianquinto, E.; Rossetti, G.; Cruciani, G.; Lorenzetti, S.; Spyrakis, F. Binding of Androgen- and Estrogen-Like Flavonoids to Their Cognate (Non)Nuclear Receptors: A Comparison by Computational Prediction. Molecules 2021, $26,1613$. [CrossRef]

228. Kowalska, M.; Nowaczyk, J.; Nowaczyk, A. $\mathrm{K}_{\mathrm{V}} 11.1, \mathrm{Na}_{\mathrm{V}} 1.5$, and Cav1.2 Transporter Proteins as Antitarget for Drug Cardiotoxicity. Int. J. Mol. Sci. 2020, 21, 8099. [CrossRef]

229. Wang, X.; Saegusa, H.; Huntula, S.; Tanabe, T. Blockade of microglial Cav1.2 $\mathrm{Ca}^{2+}$ channel exacerbates the symptoms in a Parkinson's disease model. Sci. Rep. 2019, 9, 1-13. [CrossRef]

230. Jørgensen, C.V.; Bräuner-Osborne, H. Pharmacology and physiological function of the orphan GPRC6A receptor. Basic Clin. Pharmacol. Toxicol. 2020, 126, 77-87. [CrossRef] 